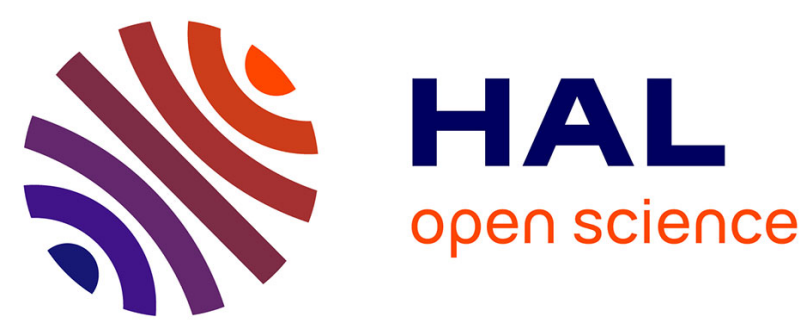

\title{
Continuous supercritical solvothermal preparation of nanostructured ceria-zirconia as supports for dry methane reforming catalysts
}

Aimery Auxéméry, Brigitte Botello Frias, Ekaterina Smal, Katarzyna

Dziadek, Gilles Philippot, Piotr Legutko, Michail Simonov, Sébastien Thomas, Andrzej Adamski, Vladislav Sadykov, et al.

\section{To cite this version:}

Aimery Auxéméry, Brigitte Botello Frias, Ekaterina Smal, Katarzyna Dziadek, Gilles Philippot, et al. Continuous supercritical solvothermal preparation of nanostructured ceria-zirconia as supports for dry methane reforming catalysts. Journal of Supercritical Fluids, 2020, 162, 104855 (10 p.). 10.1016/j.supflu.2020.104855 . hal-02570555

\section{HAL Id: hal-02570555 https://hal.science/hal-02570555}

Submitted on 12 May 2020

HAL is a multi-disciplinary open access archive for the deposit and dissemination of scientific research documents, whether they are published or not. The documents may come from teaching and research institutions in France or abroad, or from public or private research centers.
L'archive ouverte pluridisciplinaire HAL, est destinée au dépôt et à la diffusion de documents scientifiques de niveau recherche, publiés ou non, émanant des établissements d'enseignement et de recherche français ou étrangers, des laboratoires publics ou privés. 
Continuous supercritical solvothermal preparation of nanostructured ceria-zirconia as supports for dry methane reforming catalysts

Aimery Auxemery ${ }^{1}$, Brigitte Botello Frias $^{2}$, Ekaterina $\mathrm{Smal}^{3}$, Katarzyna Dziadek ${ }^{4}$, Gilles Philippot $^{1}$, Piotr Legutko ${ }^{4}$, Michail Simonov ${ }^{3}$, Sebastien Thomas ${ }^{2}$, Andrzej Adamski ${ }^{4}$, Vladislav Sadykov ${ }^{3}$, Ksenia Parkhomenko $^{2}$, Anne-Cécile Roger ${ }^{2, *}$ Cyril Aymonier ${ }^{1, *}$

${ }^{1}$ CNRS, Univ. Bordeaux, Bordeaux INP, ICMCB, UMR 5026, F-33600 Pessac, France

${ }^{2}$ Institut de Chimie et Procédés pour l'Énergie, l'Environnement et la Santé, UMR 7515

CNRS, Université de Strasbourg, Groupe “Énergie et Carburants pour un Environnement durable”, 25 rue Becquerel, 67087 Strasbourg Cedex 2, France

${ }^{3}$ Boreskov Institute of Catalysis, pr. Lavrentieva, 5; Novosibirsk State University, Pirogova str., 1, Novosibirsk , 630090, Russia

${ }^{4}$ Jagiellonian University, Faculty of Chemistry, Gronostajowa 2, 30-387 Kraków, Poland

* Corresponding authors. E-mail address: cyril.aymonier@icmcb.cnrs.fr and $\underline{\text { annececile.roger@unistra.fr }}$ 


\section{Abstract}

The nanostructured $\mathrm{Ce}_{\mathrm{x}} \mathrm{Zr}_{1-\mathrm{x}} \mathrm{O}_{2}$ systems $(0 \leq \mathrm{x} \leq 0.75)$ were prepared combining alkoxide and nitrate precursors in an ethanol/water mixture by the continuous supercritical solvothermal solgel like synthesis. They were subsequently used as supports for nickel impregnation (10 wt.\%) to obtain catalysts for dry reforming of methane (DRM) reaction. A reference $\mathrm{Ce}_{\mathrm{x}} \mathrm{Zr}_{1-\mathrm{x}} \mathrm{O}_{2}(\mathrm{x}=$ 0.50) system prepared via conventional coprecipitation method was used as a support for nickel impregnation in the comparative study of the nanostructured materials' catalytic potential. The morphological and structural properties of the prepared nanostructured supports and $\mathrm{Ni}$ containing catalysts were investigated by numerous techniques as XRD, Raman spectroscopy, SEM, TEM, EDS, chemisorption and others. The conditions of DRM reaction were chosen in order to compare the activity, the stability as well as the selectivity of coke formation in the presence of the prepared catalytic materials. It was found that the industrial catalyst leads to heavy coking in the chosen conditions with a rapid loss of activity. While the nanostructured $\mathrm{Ce}_{\mathrm{x}} \mathrm{Zr}_{1-\mathrm{x}} \mathrm{O}_{2}(0 \leq \mathrm{x} \leq 0.75)$ materials are found to be promising supports for $\mathrm{Ni}$ dispersion and coke control in DRM. In this study the nanostructured $\mathrm{Ce}_{0.50} \mathrm{Zr}_{0.50} \mathrm{O}_{2}$ material impregnated with nickel shown the highest TOF and the smallest selectivity of coke formation in DRM among other nanostructured materials. The continuous supercritical solvothermal method allows to prepare nanostructured mixed oxides materials that could be promising supports for different active metals dispersion and for coke control in the reactions where coking may be abundant.

\section{Keywords}

Dry reforming of methane, carbon dioxide valorization, nanocatalysts, nickel, mixed oxides, ceria-zirconia, supercritical solvothermal synthesis, flow synthesis 


\section{Introduction}

For more than 20 years ceria and zirconia have remained of vital scientific and industrial interests in many domains. Optimizing ceria preparation is easy because it can exist thermodynamically only in the regular cubic structure with a Fm-3m space group, while zirconia is a much more complex material to be mastered as it exhibits quite rich polymorphism, including the existence of monoclinic, tetragonal and cubic phases. Indeed, stabilization of pure zirconia is not only temperature and pressure dependent, as reported in many works $[1,2]$, but is also impurity and grain-size dependent [3-5]. The high oxygen storage capacity (OSC) of ceria $[6,7]$ allows many interesting applications such as: $\mathrm{CO}_{2}$ capture/release processes [8], three-way catalysis (TWC) $[9,10]$ etc. However, when used as a catalyst, ceria faces a high risk of sintering at high operating temperatures [6] and the incorporation of doping elements such as zirconium has proven to be helpful to increase bulk oxygen mobility and to prevent ceria from sintering at temperatures around $700-750{ }^{\circ} \mathrm{C}$ [11]. Linking improvement of ceria and zirconia properties to environmentally friendly syntheses techniques is proposed in this work by using the continuous supercritical synthesis as an alternative to conventional methods [12, $13]$.

Among others, the main solvents used to produce continuously materials in supercritical fluid are carbon dioxide, water, alcohols or mixtures of them [14]. The uniform conditions rapidly attained within the supercritical solvent combined to the high supersaturation conditions lead to the formation of highly crystallized nanosized oxide particles, exhibiting a very narrow grain size distribution [14]. Hence, this technique has been extensively used to successfully synthesize various metal oxides with fine control over chemical and phase compositions, size, morphology and structure [3, 15-20]. 
Improvement of catalytic properties of both $\mathrm{ZrO}_{2}$ and $\mathrm{CeO}_{2}$ systems through cationic substitution, respectively with $\mathrm{Ce}^{\mathrm{n+}}(\mathrm{n}=3,4)$ and $\mathrm{Zr}^{4+}$ cations, has been largely studied at intermediate temperatures by many research groups in both supercritical water and alcoholic solutions $[3,5,17,19-23]$.

In this work, we introduce the advantages of combining alkoxide and nitrate precursors in a supercritical ethanol/water mixture for the supercritical sol gel like synthesis of the $\mathrm{CeO}_{2}-\mathrm{ZrO}_{2}$ system $\left(\mathrm{Ce}_{\mathrm{x}} \mathrm{Zr}_{1-\mathrm{x}} \mathrm{O}_{2} ; 0 \leq \mathrm{x} \leq 0.75\right)$ towards dedicated catalytic purposes. The choice of a 0.29:0.71 ethanol to water molar ratio and $400{ }^{\circ} \mathrm{C}$ and $25 \mathrm{MPa}$ as operating conditions is based on previous research works on the synthesis of highly crystallized and narrow sized metal oxide nanoparticles with fine control over structure and morphology [24]. The nanostructured $\mathrm{Ce}_{\mathrm{x}} \mathrm{Zr}_{1-}$ ${ }_{x} \mathrm{O}_{2}$ systems were subsequently used as supports for nickel to obtain catalysts for dry reforming of methane (DRM) reactions for the comparative study of our synthesized nanostructured supports and a reference $\mathrm{Ce}_{\mathrm{x}} \mathrm{Zr}_{1-\mathrm{x}} \mathrm{O}_{2}(\mathrm{x}=0.50)$ system prepared via conventional methods.

In DRM reactions, the critical parameters are large coking of the catalysts causing a rapid loss of activity, and sintering of the active metal at the high reaction temperatures needed for complete $\mathrm{CO}_{2}$ and $\mathrm{CH}_{4}$ conversions. To overcome the coking formation drawback, different options are possible. Addition of oxygen in the feed to perform the oxidative DRM reduces drastically the coking of the catalyst but in the same time causes the deactivation due to the reoxidation of the active metals in the catalyst [25]; very fine reaction parameters control is necessary as well as the kinetic analysis is recommended for the process optimization and reactor design. The use of supports with high oxygen storage capacity is another option to overcome the deactivation of catalysts during DRM. Modified fluorite-like supports, doublelayered hydroxides, hydrotalcites, nanocatalysts and especially mixed oxides as $\mathrm{Ce}_{\mathrm{x}} \mathrm{Zr}_{1-\mathrm{x}} \mathrm{O}_{2}$ 
materials are believed to be promising supports for good $\mathrm{Ni}$ dispersion and coke control in DRM [26, 27].

For this study the metallic nickel was supported via wet impregnation on the calcined nanostructured $\mathrm{Ce}_{\mathrm{x}} \mathrm{Zr}_{1-\mathrm{x}} \mathrm{O}_{2}(0 \leq \mathrm{x} \leq 0.75)$ supports prepared by continuous supercritical solvothermal method. The catalysts were fully characterized prior and post DRM tests and results were compared to those obtained on the reference $\mathrm{Ce}_{0.50} \mathrm{Zr}_{0.50} \mathrm{O}_{2}$ catalyst support (provided by Solvay) prepared via a conventional coprecipitation method.

\section{Material and methods}

\subsection{Preparation of catalysts}

\subsubsection{Precursors}

$\mathrm{Ce}_{\mathrm{x}} \mathrm{Zr}_{1-\mathrm{x}} \mathrm{O}_{2}(\mathrm{x}=0.00 ; 0.25 ; 0.50 ; 0.75)$ nanostructured supports were prepared with the supercritical fluid method starting from the following precursors: ammonium cerium (IV) nitrate hexahydrate (99.99\% Sigma-Aldrich) $\mathrm{Ce}\left(\mathrm{NH}_{4}\right)_{2}\left(\mathrm{NO}_{3}\right)_{6} .6 \mathrm{H}_{2} \mathrm{O}$ and zirconium propoxide solution, 70 wt.\% in 1-propanol (Sigma-Aldrich) $\mathrm{Zr}\left(\mathrm{OCH}_{2} \mathrm{CH}_{2} \mathrm{CH}_{3}\right)_{4}$. Precursors were used as received and were diluted in absolute ethanol (reagent grade, AtlanticLabo). $\mathrm{Ni}\left(\mathrm{NO}_{3}\right)_{2} \cdot 6 \mathrm{H}_{2} \mathrm{O}$ (Sigma-Aldrich, $\geq 98.5 \%$ ) was used as precursor of nickel active phase.

\subsubsection{Supercritical fluid synthesis system and protocol}

In order to achieve a total cation concentration of $10 \mathrm{mM}$ for each sample of the $\mathrm{Ce}_{\mathrm{x}} \mathrm{Zr}_{1-\mathrm{x}} \mathrm{O}_{2}$ series $(x=0.00 ; 0.25 ; 0.50 ; 0.75)$, proper amounts of precursors were dissolved in absolute ethanol inside a glovebox under controlled argon atmosphere. Subsequently, the precursor solution was stirred until full dissolution of precursors and placed outside the glove box. A 2 $\mathrm{mL} \mathrm{m^{-1 }}$ argon flow was fed through the solution to avoid exposure to air during the syntheses. 
All synthetic cycles were performed at $\mathrm{T}=400{ }^{\circ} \mathrm{C}$ and $\mathrm{p}=25 \mathrm{MPa}$. In these operating conditions, the ethanol / water mixture with a $0.29 / 0.71$ molar ratio was well above its critical coordinates $\left(\mathrm{T}_{\mathrm{c}}=283.55^{\circ} \mathrm{C}, \mathrm{p}_{\mathrm{c}}=11.69 \mathrm{MPa}\right.$, NIST Standard Reference Database $)$.

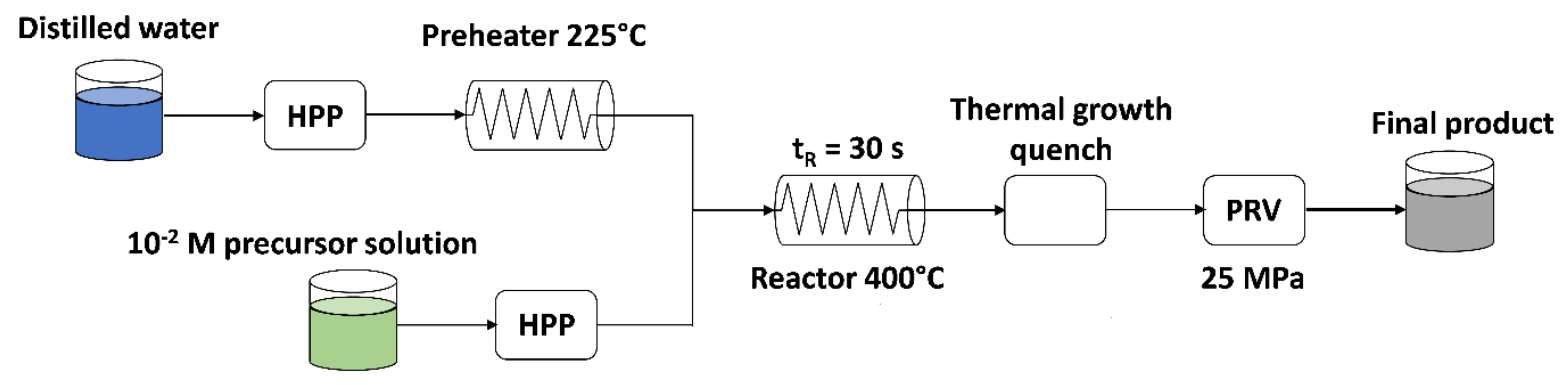

Figure 1. Scheme of the set-up used for synthesizing the $\mathrm{Ce}_{\mathrm{x}} \mathrm{Zr}_{1-\mathrm{x}} \mathrm{O}_{2}(0 \leq \mathrm{x} \leq 0.75)$ nanoparticles (HPP=high pressure pump, $t_{R}=$ reaction time, $P R V=$ pressure regulating valve)

The experimental custom-built, flow reactor used for the supercritical synthesis of the $\mathrm{Ce}_{\mathrm{x}} \mathrm{Zr}_{1-}$ ${ }_{\mathrm{x}} \mathrm{O}_{2}$ nanostructured support series is shown in Figure 1. The stainless-steel reactor used was equipped with two injection lines. The first injection line was used to feed the reactor with the precursor solution dissolved in absolute ethanol while the second injection line was used to flow preheated de-ionized water at $225^{\circ} \mathrm{C}$. At the mixing point between the two injection lines, the temperature was set to $150{ }^{\circ} \mathrm{C}$ prior entering the reactor $\left(\mathrm{p}=25 \mathrm{MPa}, \mathrm{T}=400{ }^{\circ} \mathrm{C}\right.$ ) where the crystallization of nanoparticles occurred under supercritical conditions. The residence time inside the reactor was 30 seconds.

Right after the reactor is located a cold zone to quench the nanoparticle growth. The nanoparticle solution is then recovered in suspension after the pressure regulating valve at ambient conditions then centrifuged at $10000 \mathrm{rpm}$ for 20 minutes. The $\mathrm{CeO}_{2}-\mathrm{ZrO}_{2}$ nanoparticles are then separated from the supernatant and left to dry at ambient conditions. Fresh $\mathrm{Ce}_{\mathrm{x}} \mathrm{Zr}_{1-\mathrm{x}} \mathrm{O}_{2}$ 
samples will be hereafter referred to as $\mathrm{ZrO}_{2}, \mathrm{Ce}_{0.25} \mathrm{Zr}_{0.75} \mathrm{O}_{2}, \mathrm{Ce}_{0.50} \mathrm{Zr}_{0.50} \mathrm{O}_{2}$ and $\mathrm{Ce}_{0.75} \mathrm{Zr}_{0.25} \mathrm{O}_{2}$ corresponding to $\mathrm{x}=0.00 ; 0.25 ; 0.50$ and 0.75 , respectively (Table 1 ).

Fresh samples were calcined at $800{ }^{\circ} \mathrm{C}$ for $6 \mathrm{~h}$ in air with a heating rate of $4{ }^{\circ} \mathrm{C} \mathrm{min}^{-1}$. Calcined samples will be referred hereafter to as $\mathrm{ZrO}_{2}-800, \mathrm{Ce}_{0.25} \mathrm{Zr}_{0.75} \mathrm{O}_{2}-800, \mathrm{Ce}_{0.50} \mathrm{Zr}_{0.50} \mathrm{O}_{2}-800$ and $\mathrm{Ce}_{0.75} \mathrm{Zr}_{0.25} \mathrm{O}_{2}-800$ (Table 1).

A nickel loading of $10 \mathrm{wt} \%$ (theoretical) was selected. Nickel was loaded on all the calcined $\mathrm{Ce}_{\mathrm{x}} \mathrm{Zr}_{1-\mathrm{x}} \mathrm{O}_{2}$ support samples using classical wet impregnation method. The proper amount of $\mathrm{Ni}\left(\mathrm{NO}_{3}\right)_{2} \cdot 6 \mathrm{H}_{2} \mathrm{O}$ salt was dissolved in a small quantity of distilled water, and then $0.15-0.20 \mathrm{~g}$ of $\mathrm{Ce}_{\mathrm{x}} \mathrm{Zr}_{1-\mathrm{x}} \mathrm{O}_{2}-800$ powder was added. The mixture was stirred for $1 \mathrm{~h}$, afterwards, water was partly evaporated at $60-70{ }^{\circ} \mathrm{C}$, then dried completely in the oven during $8 \mathrm{~h}$ at $100{ }^{\circ} \mathrm{C}$. Finally, the materials were calcined at $800{ }^{\circ} \mathrm{C}$ for $6 \mathrm{~h}$ in air with a heating rate of $4{ }^{\circ} \mathrm{C} \mathrm{min}{ }^{-1}$. Nickelcontaining samples will be referred to as $\mathrm{Ni} / \mathrm{ZrO}_{2}, \mathrm{Ni} / \mathrm{Ce}_{0.25} \mathrm{Zr}_{0.75} \mathrm{O}_{2}, \mathrm{Ni} / \mathrm{Ce}_{0.50} \mathrm{Zr}_{0.50} \mathrm{O}_{2}$ and $\mathrm{Ni} / \mathrm{Ce}_{0.75} \mathrm{Zr}_{0.25} \mathrm{O}_{2}$ (Table 1).

Additionally, one $\mathrm{Ce}_{0.50} \mathrm{Zr}_{0.50} \mathrm{O}_{2}$ support from Solvay, referred as $\mathrm{Ce}_{0.50} \mathrm{Zr}_{0.50} \mathrm{O}_{2}$-ind, was chosen as reference to be compared with the synthesized nanostructured $\mathrm{Ce}_{0.50} \mathrm{Zr}_{0.50} \mathrm{O}_{2}-800$ material. This sample was prepared by a traditional coprecipitation synthesis and was chosen for comparison of the supercritical solvothermal preparation and non-supercritical solvothermal preparation on the example of one composition. The reference sample underwent the same thermal treatment as the other samples described above - calcination step, followed by wet impregnation with nickel precursor and final calcination at $800{ }^{\circ} \mathrm{C}$ for $6 \mathrm{~h}$ in air with a heating rate of $4{ }^{\circ} \mathrm{C} \min ^{-1}$. 
Table 1. List of synthesized samples

\begin{tabular}{lll}
\hline Fresh supports & Calcined supports & Corresponding catalysts \\
\hline $\mathrm{ZrO}_{2}$ & $\mathrm{ZrO}_{2}-800$ & $\mathrm{Ni} / \mathrm{ZrO}_{2}$ \\
$\mathrm{Ce}_{0.25} \mathrm{Zr}_{0.75} \mathrm{O}_{2}$ & $\mathrm{Ce}_{0.25} \mathrm{Zr}_{0.75} \mathrm{O}_{2}-800$ & $\mathrm{Ni} / \mathrm{Ce}_{0.25} \mathrm{Zr}_{0.75} \mathrm{O}_{2}$ \\
$\mathrm{Ce}_{0.50} \mathrm{Zr}_{0.50} \mathrm{O}_{2}$ & $\mathrm{Ce}_{0.50} \mathrm{Zr}_{0.50} \mathrm{O}_{2}-800$ & $\mathrm{Ni} / \mathrm{Ce}_{0.50} \mathrm{Zr}_{0.50} \mathrm{O}_{2}$ \\
$\mathrm{Ce}_{0.75} \mathrm{Zr}_{0.25} \mathrm{O}_{2}$ & $\mathrm{Ce}_{0.75} \mathrm{Zr}_{0.25} \mathrm{O}_{2}-800$ & $\mathrm{Ni} / \mathrm{Ce}_{0.75} \mathrm{Zr}_{0.25} \mathrm{O}_{2}$ \\
- & $\mathrm{Ce}_{0.50} \mathrm{Zr}_{0.50} \mathrm{O}_{2}$-ind & $\mathrm{Ni} / \mathrm{Ce}_{0.50} \mathrm{Zr}_{0.50} \mathrm{O}_{2}$-ind \\
\hline
\end{tabular}

\subsection{Materials characterization}

\subsubsection{Powder X-ray diffraction (XRD)}

For fresh supports, room temperature powder X-ray diffraction (XRD) patterns were recorded on a PANalytical diffractometer with the Bragg-Brentano $\theta-2 \theta$ geometry, over the $10<2 \theta<$ $130^{\circ}$ range, with an angular step of $0.0167^{\circ}$ and a step time of $0.6 \mathrm{~s}$. The diffractometer was equipped with a secondary monochromator and the $\mathrm{CuK} \alpha_{1}=1.5418 \AA$ radiation was generated at $45 \mathrm{kV}$ and $40 \mathrm{~mA}$. For both calcined supports and the corresponding catalysts, X-ray diffraction patterns were recorded on a Brucker D8 Advanced Powder Diffraction System with a VANTEC detector side and Ni filtered $\mathrm{CuK} \alpha_{1}$ radiation, over $2 \theta$ range $20-80^{\circ}$ using a step size of $0.01^{\circ}$ and a step time of $0.2 \mathrm{~s}$. Prior to measurements, powders were ground and sieved using a $40 \mu \mathrm{m}$ sieve.

Nanocrystals parameter refinements were performed using the FullProf_Suite ${ }^{\bigodot}$ software with the Thompson-Cox-Hastings model to describe the peak profiles. In the purpose of this study, refined parameters were the scale factor for each different phase, the instrumental zero, unit cell parameters, Gaussian and Lorentzian contributions to the total peak broadening, and the microstructural strain parameter. The background, based on an eight-position background file generated with FullProf_Suite ${ }^{\complement}$, was also refined. 


\subsubsection{Raman spectroscopy}

Raman spectra were collected at room temperature on a Thermo Scientific DXR Raman spectrometer using an argon ion source $\left(\lambda_{\mathrm{exc}}=532 \mathrm{~nm}\right)$ in a backscattering geometry. Focus was made using a x10 magnification objective with a laser spot of approximately $3 \mu \mathrm{m}^{2}$. A resolution of $3 \mathrm{~cm}^{-1}$ was defined over the $150-3500 \mathrm{~cm}^{-1}$ domain. The data were collected and integrated using the OMNIC software.

\subsubsection{Scanning electron microscopy (SEM)}

Scanning electron microscopy (SEM) measurements were conducted on an electron microscope ZEISS GEMINI SEM 500 with a resolution of $1.2 \mathrm{~nm}$ at $500 \mathrm{~V}$ and $1.1 \mathrm{~nm}$ at $1 \mathrm{kV}$, equipped with an Inlens secondary electron (SE) detector and a SE2 detector.

\subsubsection{Transmission electron microscopy (TEM) and Electron dispersive energy (EDS)}

Particle size, morphology of powders and compositions were examined using a high resolution transmission electron microscope (HR-TEM FEG JEOL 2200FS) equipped with a highresolution camera. The accelerating voltage used was $200 \mathrm{keV}$ and Digital Micrograph software was used to acquire the data.

Electron dispersive energy spectroscopy was performed during transmission electron microscopy analysis by probing $\mathrm{L}_{\alpha}=2.042$ and $4.839 \mathrm{keV}$ for zirconium and cerium, respectively, and a probe current of $2.562 \mathrm{nA}$. For each sample, 15 scans of $270 \mathrm{~s}$ were performed on three different zones in order to determine the composition and homogeneity of the samples. Digital micrograph software was used to interpret the collected images. Powders were dispersed in ethanol and ultrasonicated for better dispersion prior to be placed on 200 mesh carbon-supported copper grids. 


\subsubsection{Nitrogen adsorption-desorption (BET method)}

Nitrogen adsorption-desorption measurements were performed at $-196{ }^{\circ} \mathrm{C}$ on a Micromeritics ASAP 2420 apparatus. Specific surface areas were calculated using the Brunauer-EmmetTeller (BET) method. Samples were previously outgased at $200{ }^{\circ} \mathrm{C}$ for $6 \mathrm{~h}$ to remove the adsorbed moisture/ air components.

\subsubsection{Metallic surface area measurements by hydrogen adsorption}

Prior to analysis the samples were reduced at $450{ }^{\circ} \mathrm{C}$ in a flow of $10 \mathrm{vol} . \%$ of $\mathrm{H}_{2}$ in argon, total flow $50 \mathrm{~mL} \mathrm{~min}{ }^{-1}$, heating rate $10{ }^{\circ} \mathrm{C} \mathrm{min}^{-1}$; after $6 \mathrm{~h}$ of the hold time the samples were purged with pure argon and cooled down till $50{ }^{\circ} \mathrm{C}$. After the temperature stabilization hydrogen was adsorbed by pulses with intermediate argon purge. The nickel metallic surface area was calculated using the estimation of the adsorbed hydrogen from the mathematical analysis of the pulses. The Micromeritics AutoChem II 2920 apparatus was used for these measurements.

\subsubsection{Temperature programmed oxidation (TPO)}

Temperature programmed oxidation coupled with thermogravimetric analysis (TPO-TGA) was used to quantify the amount of carbonaceous deposits on the Ni-containing catalysts after the catalytic tests. The temperature was ramped at a rate of $10^{\circ} \mathrm{C} \cdot \mathrm{min}^{-1}$ from room temperature to $900{ }^{\circ} \mathrm{C}$, while a mixture of $20 \%$ oxygen in nitrogen (synthetic air purchased from SOL France) was passed through the catalyst at $1 \mathrm{~atm}$. Quantification of carbon deposition was possible by monitoring the weight loss by on-line thermogravimetric analysis (TGA) on the Q 5000IR equipment from TA Instruments.

\subsection{Catalytic tests}

The catalytic activity measurements were performed in a I-shape fixed bed quartz reactor with an inner diameter of $6 \mathrm{~mm}$. The catalyst bed was placed between two pieces of quartz wool with gas flows pointing downwards. Prior to methane dry reforming reaction, $10 \mathrm{mg}$ of the 
catalyst powder mixed with $30 \mathrm{mg}$ of $\beta$-SiC (provided by SICAT, particles size $0.125-0.150$ $\mathrm{mm}$ ) were reduced under a $5 \mathrm{NmLmin}^{-1}$ flow of pure $\mathrm{H}_{2}$ at $450{ }^{\circ} \mathrm{C}$ for $6 \mathrm{~h}$. After the pretreatment, a feed mixture consisting of $\mathrm{CH}_{4}: \mathrm{CO}_{2}: \mathrm{N}_{2}: \mathrm{Ar}=1: 1: 0.5: 4.5$ (molar) was introduced into the reactor, $\mathrm{N}_{2}$ served as an internal standard. The total flow rate was equal to $70 \mathrm{NmLmin}^{-1}$ (GHSV $\left.420 \mathrm{Lh}^{-1} \mathrm{~g}_{\mathrm{cat}}{ }^{-1}(\mathrm{STP})\right)$. The reforming tests were studied with an increase of temperature from 550 to $800{ }^{\circ} \mathrm{C}$ with a stabilization of $0.5 \mathrm{~h}$ every $50{ }^{\circ} \mathrm{C}$. Isothermal experiments at $700{ }^{\circ} \mathrm{C}$ were also performed to study the stability of the catalysts. Gas bottles of $\mathrm{CH}_{4}, \mathrm{CO}_{2}, \mathrm{H}_{2}, \mathrm{~N}_{2}$ and Ar were purchased from Air Liquide and SOL France. Gas flows were regulated by Brooks SLA 5850S mass flow controllers connected to Brooks 0254 secondary electronics. Temperature was regulated by a PID controller. Water was collected in a trap cooled with the Huber TC40E thermostat. Effluent gases were analyzed online by an Inficon 3000 microchromatograph equipped with Molsieve $5 \AA$ and Poraplot Q columns and TCD detectors. A test with pure $\beta$-SiC did not show any conversion of methane neither of $\mathrm{CO}_{2}$ at all studied temperatures.

\section{Results and discussion}

\subsection{Materials characterization}

Firstly, all fresh samples were characterized before further calcination and impregnation with an aqueous solution of nickel nitrate.

Normalized X-ray diffraction patterns of fresh $\mathrm{Ce}_{\mathrm{x}} \mathrm{Zr}_{1-\mathrm{x}} \mathrm{O}_{2}(0 \leq \mathrm{x} \leq 0.75)$ nanopowders are presented in Figure 2. The diffraction pattern of $\mathrm{ZrO}_{2}$ exhibits a mixture of both monoclinic $\left(\mathrm{P} 2_{1} / \mathrm{c}\right)$ and tetragonal $\left(\mathrm{P} 4_{2} / \mathrm{nmc}\right)$ crystal structures (Figure $\left.2 \mathrm{a}\right)$. The inset of Figure 2 displays $\mathrm{ZrO}_{2}$ diffraction pattern in the $15<2 \theta<40$ range with \# and $*$ being reflections from the monoclinic and tetragonal structures, respectively. Contributions from the monoclinic $\mathrm{ZrO}_{2}$ are 
visible at $2 \theta$ of $17.5,24.2,28.2,31.1$ and $34.7^{\circ}$ corresponding to the $(100)_{\mathrm{m}},(011)_{\mathrm{m}}$ and $(110)_{\mathrm{m}}$, $(11-1)_{\mathrm{m}}$ and $(111)_{\mathrm{m}}$ diffracting planes, respectively. Contributions from the tetragonal $\mathrm{ZrO}_{2}$ are visible at $2 \theta$ of 30.3 and $34.7^{\circ}$ corresponding to the $(111)_{t}$ and $(101)_{t}$ planes, respectively. A major overlap of the $(111)_{\mathrm{m}}$ and $(101)_{\mathrm{t}}$ Bragg reflections is observed for this sample. Regarding the other $\mathrm{Ce}_{\mathrm{x}} \mathrm{Zr}_{1-\mathrm{x}} \mathrm{O}_{2}$ nanopowders $(0.25 \leq \mathrm{x} \leq 0.75)$ (Figure $2 \mathrm{~b}, 2 \mathrm{c}$ and $2 \mathrm{~d}$ ), they are all tetragonal. Moreover, we can observe as expected a peak shift to smaller $2 \theta$ as the Ce content increases. Indeed, the cerium atomic radius $(185 \mathrm{pm})$ being bigger than the zirconium one (155 pm), when increasing the cerium content in the solid solution, the lattice gets bigger leading to a peak shift

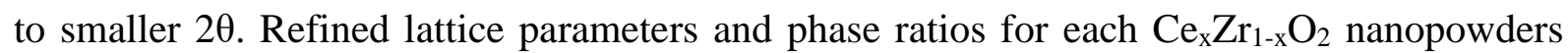
support, obtained from FullProf_suite ${ }^{\bigodot}$, are listed in Table 2, along with the crystallographic information files. According to Rietveld refinements, $\mathrm{ZrO}_{2}$ nanopowder is composed of 34 vol. $\%$ of monoclinic phase and 66 vol. $\%$ of the tetragonal one. The average crystallite sizes (A.C.S.) calculated from XRD patterns and based on Rietveld refinements are for monoclinic and tetragonal $\mathrm{ZrO}_{2} 5.4$ and $5.8 \mathrm{~nm}$, respectively. A.C.S. of tetragonal $\mathrm{Ce}_{0.25} \mathrm{Zr}_{0.75} \mathrm{O}_{2}$, $\mathrm{Ce}_{0.50} \mathrm{Zr}_{0.50} \mathrm{O}_{2}$ and $\mathrm{Ce}_{0.75} \mathrm{Zr}_{0.25} \mathrm{O}_{2}$ powders are 4.9, 5.3 and $5.0 \mathrm{~nm}$, respectively.

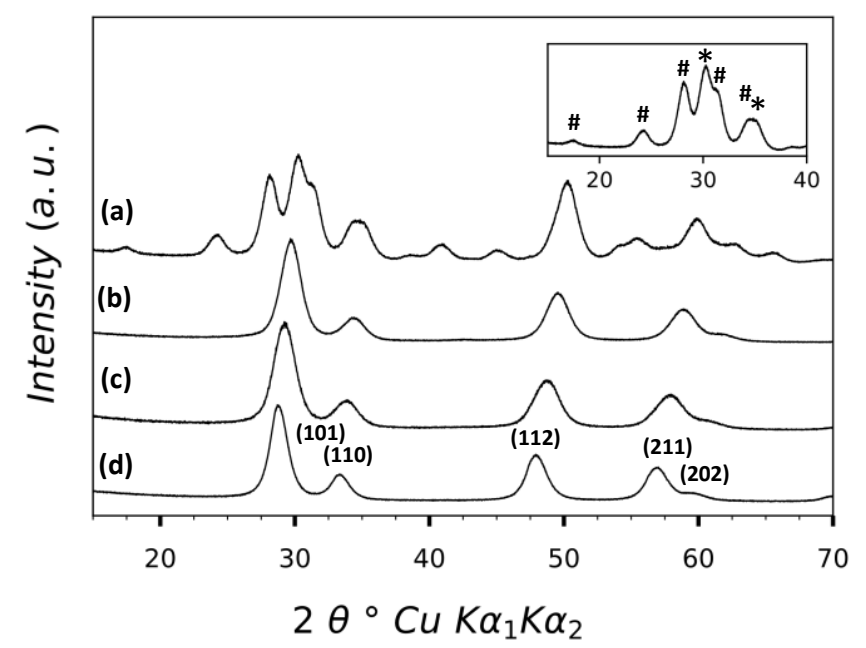


Figure 2. Powder $\mathrm{X}$-ray diffraction patterns of the fresh samples a) $\mathrm{ZrO}_{2}$, b) $\mathrm{Ce}_{0.25} \mathrm{Zr}_{0.75} \mathrm{O}_{2}$, c) $\mathrm{Ce}_{0.50} \mathrm{Zr}_{0.50} \mathrm{O}_{2}$ and d) $\mathrm{Ce}_{0.75} \mathrm{Zr}_{0.25} \mathrm{O}_{2}$. \# and * denote Bragg reflexions for the monoclinic and tetragonal structures of $\mathrm{ZrO}_{2}$, respectively.

Table 2. Structural and morphological nanoparticle characteristics.

\begin{tabular}{|c|c|c|c|c|c|c|}
\hline Sample & Phase & $\begin{array}{l}\text { Space } \\
\text { group }\end{array}$ & $\begin{array}{c}\text { Lattice } \\
\text { parameters } \\
\text { (̊) }\end{array}$ & $\begin{array}{c}\text { A.C.S.* } \\
(\mathrm{nm}) \\
\text { XRD }\end{array}$ & $\begin{array}{c}\text { A.P.S. } \\
(\mathrm{nm}) \\
\text { TEM }\end{array}$ & $\begin{array}{l}\text { CIF file } \\
\text { (XRD) }\end{array}$ \\
\hline \multirow[t]{2}{*}{$\overline{\mathrm{ZrO}_{2}}$} & $\begin{array}{l}\text { Monoclinic } \\
(34 \text { vol } \%)\end{array}$ & $\mathrm{P} 2{ }_{1} / \mathrm{c}$ & $\begin{array}{l}a=5.151 \\
b=5.204 \\
c=5.327 \\
\beta=99.182\end{array}$ & 5.4 & $3.9 \pm 0.7$ & ICSD 157403 \\
\hline & $\begin{array}{l}\text { Tetragonal } \\
(66 \text { vol\%) }\end{array}$ & $\mathrm{P} 4_{2} / \mathrm{nmc}$ & $\begin{array}{l}a=3.601 \\
c=5.183\end{array}$ & 5.8 & $3.9 \pm 0.7$ & ICSD 66781 \\
\hline $\mathrm{Ce}_{0.25} \mathrm{Zr}_{0.75} \mathrm{O}_{2}$ & Tetragonal & $\mathrm{P} 4_{2} / \mathrm{nmc}$ & $\begin{array}{l}a=3.660 \\
c=5.224\end{array}$ & 4.9 & $3.7 \pm 0.6$ & ICSD 66781 \\
\hline $\mathrm{Ce}_{0.50} \mathrm{Zr}_{0.50} \mathrm{O}_{2}$ & Tetragonal & $\mathrm{P} 4_{2} / \mathrm{nmc}$ & $\begin{array}{l}a=3.731 \\
c=5.284\end{array}$ & 5.3 & $4.0 \pm 0.8$ & ICSD 66781 \\
\hline $\mathrm{Ce}_{0.75} \mathrm{Zr}_{0.25} \mathrm{O}_{2}$ & Tetragonal & $\mathrm{P} 4_{2} / \mathrm{nmc}$ & $\begin{array}{l}a=3.800 \\
c=5.327\end{array}$ & 5.0 & $4.3 \pm 0.9$ & ICSD 66781 \\
\hline
\end{tabular}

* average crystallite sizes, ${ }^{\not}$ average particle sizes

Particle size distribution and morphology of the synthesized fresh $\mathrm{Ce}_{\mathrm{x}} \mathrm{Zr}_{1-\mathrm{x}} \mathrm{O}_{2}(0 \leq \mathrm{x} \leq 0.75)$ nanopowders were analyzed by TEM and EDS. Figure 3 represents the TEM images of the fresh samples together with average particle size distribution and EDS contrast images. Moreover, for the $\mathrm{ZrO}_{2}$ sample a micrograph of a single nanocrystal is shown. For all analyzed fresh samples, the observed nanoparticles are smaller than $5 \mathrm{~nm}$ and exhibit spherical shapes 
with very narrow size distribution. The average particle sizes (A.P.S.) determined from TEM images are summarized in Table 2. The A.P.S. are similar to A.C.S. obtained by Rietveld refinements from XRD results, suggesting that the prepared nanoparticles are individual crystals. As it can be observed from the micrograph of the $\mathrm{ZrO}_{2}$ sample, the lattice planes suggest a high degree of crystallinity, which was expected from the continuous supercritical solvothermal method of materials preparation. EDS analysis confirms the homogeneity of the samples by showing uniform distribution of cerium and zirconium centers in the individual nanocrystals of mixed oxide materials (Figure 3). 


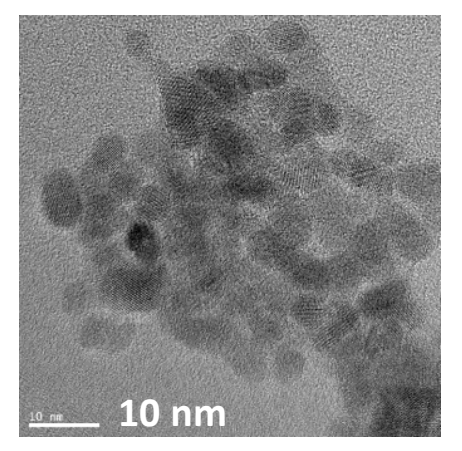

a
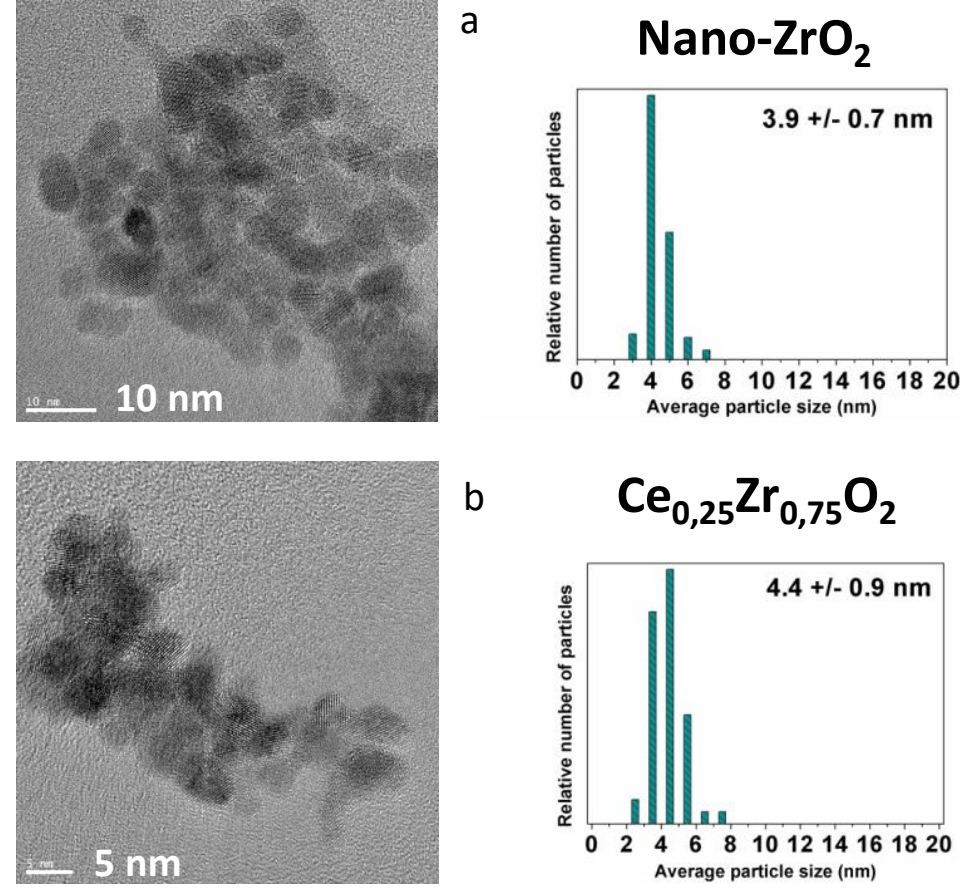

b

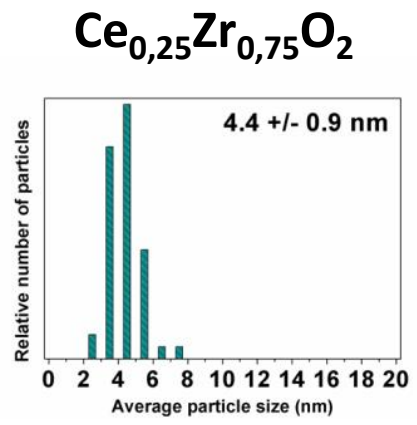

C
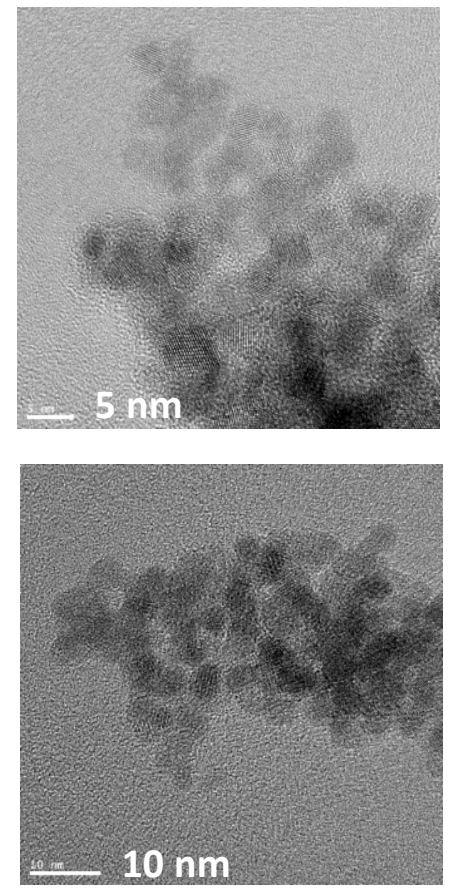

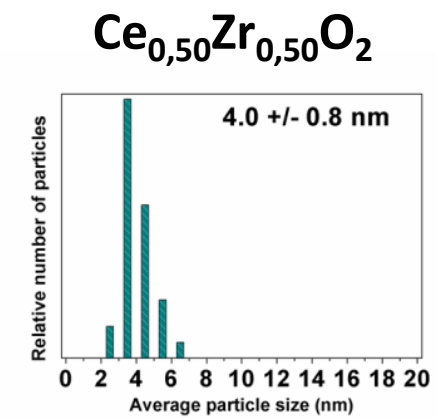

d

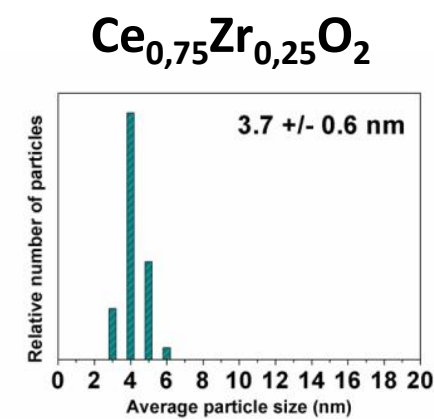

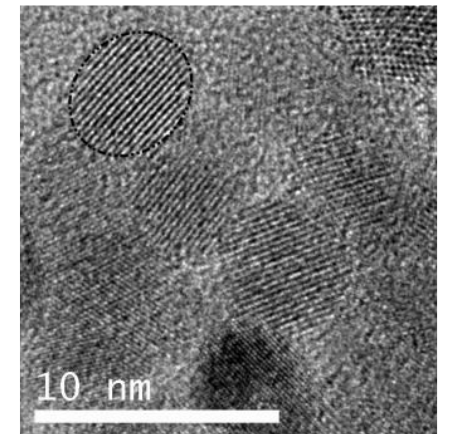
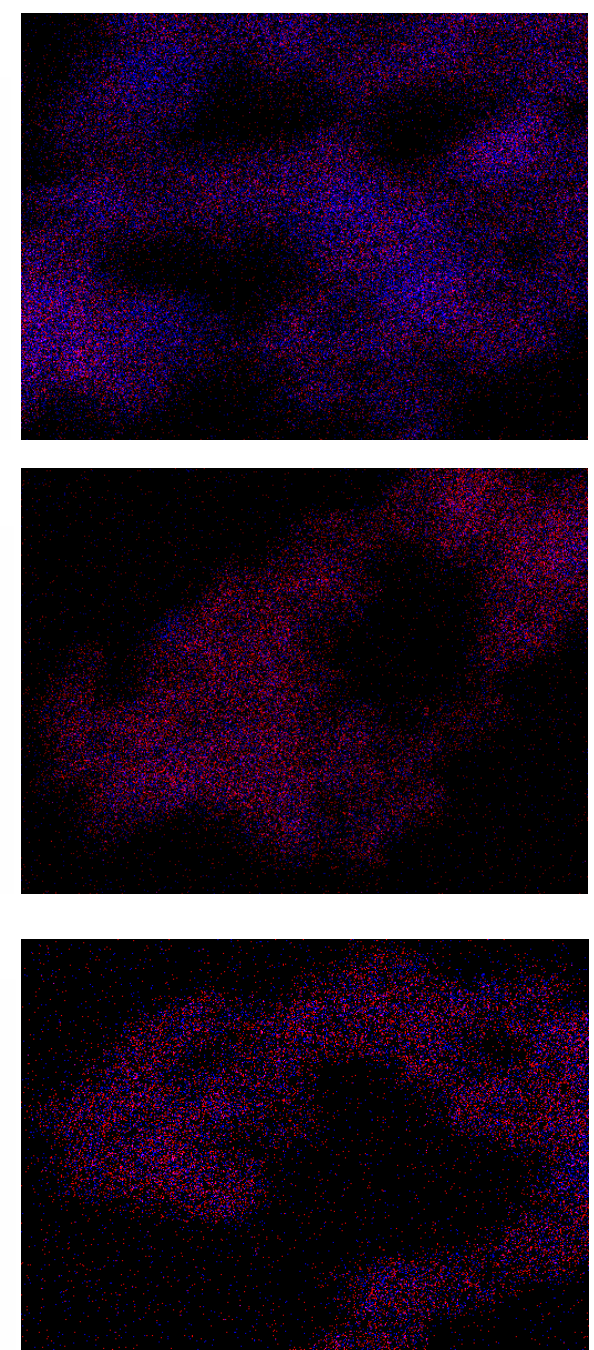

Figure 3. TEM images, particle size distributions and EDS contrast images (in blue and red Ce and Zr centers, respectively) of fresh a) $\mathrm{ZrO}_{2}$, b) $\mathrm{Ce}_{0.25} \mathrm{Zr}_{0.75} \mathrm{O}_{2}$, c) $\mathrm{Ce}_{0.50} \mathrm{Zr}_{0.50} \mathrm{O}_{2}$ and d) $\mathrm{Ce}_{0.75} \mathrm{Zr}_{0.25} \mathrm{O}_{2}$. On the top right is displayed a zoom of an individual crystal of $\mathrm{ZrO}_{2}$. 
As it is sensitive to any displacements of light elements such as oxygen inside the crystal lattice, Raman spectroscopy is a reliable technique to characterize local crystal structures and was therefore used to characterize structurally in-depth the series of nanopowders synthesized in this study. Figure 4 shows the normalized Raman spectra for all investigated fresh $\mathrm{Ce}_{\mathrm{x}} \mathrm{Zr}_{1-\mathrm{x}} \mathrm{O}_{2}$ powders in the $160-1000 \mathrm{~cm}^{-1}$ domain, where (a), (b), (c) and (d) are attributed to $\mathrm{ZrO}_{2}$, $\mathrm{Ce}_{0.25} \mathrm{Zr}_{0.75} \mathrm{O}_{2}, \mathrm{Ce}_{0.50} \mathrm{Zr}_{0.50} \mathrm{O}_{2}$ and $\mathrm{Ce}_{0.75} \mathrm{Zr}_{0.25} \mathrm{O}_{2}$, respectively. The position of each Raman mode, their associated symmetries used for their assignment are listed in Table S1, in supplementary information [28-33].

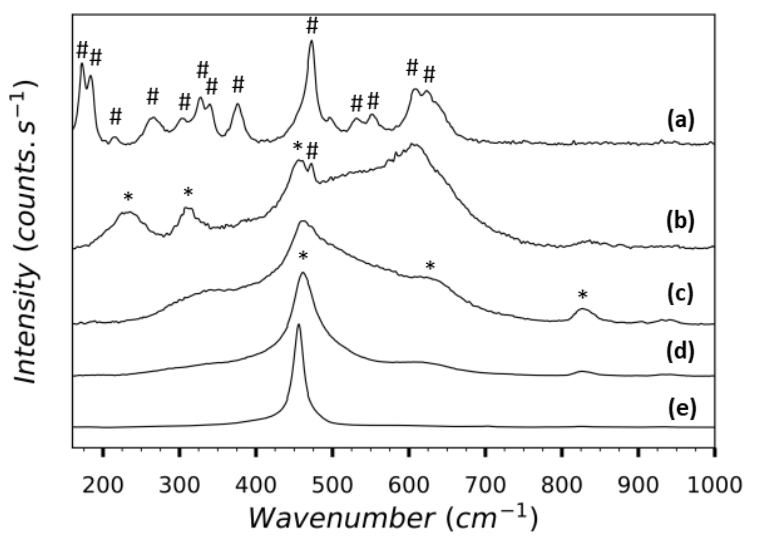

Figure 4. Raman spectra of fresh a) $\mathrm{ZrO}_{2}$, b) $\mathrm{Ce}_{0.25} \mathrm{Zr}_{0.75} \mathrm{O}_{2}$, c) $\mathrm{Ce}_{0.50} \mathrm{Zr}_{0.50} \mathrm{O}_{2}$, d) $\mathrm{Ce}_{0.75} \mathrm{Zr}_{0.25} \mathrm{O}_{2}$ and e) $\mathrm{CeO}_{2}$ powders. \# and * denotes Raman active modes for the monoclinic and tetragonal structures, respectively.

A structure difference is clearly visible between powders $\mathrm{ZrO}_{2}$ (Figure $4 \mathrm{a}$ ) and $\mathrm{Ce}_{0.25} \mathrm{Zr}_{0.75} \mathrm{O}_{2}$ (Figure $4 b$ ). While the former contains a mixture of both tetragonal and monoclinic phases, the latter exhibits mainly the tetragonal one. The difference is less visible between $\mathrm{Ce}_{0.50} \mathrm{Zr}_{0 .}{ }_{50} \mathrm{O}_{2}$ (Figure $4 \mathrm{c}$ ) and $\mathrm{Ce}_{0.75} \mathrm{Zr}_{0.25} \mathrm{O}_{2}$ (Figure $4 \mathrm{~d}$ ), the main difference being the quasi absence of signal at $\approx 330,630$ and $835 \mathrm{~cm}^{-1}$ for the latter. For $\mathrm{ZrO}_{2}$ (Figure 4a), out of the 18 theoretical active Raman modes expected for monoclinic $\mathrm{ZrO}_{2}\left(9 \mathrm{~A}_{\mathrm{g}}+9 \mathrm{~B}_{\mathrm{g}}\right)$ [30], only 13 modes are visible: $7 \mathrm{Ag}$ modes located at: 172, 184, 304, 340, 552, 623 and $637 \mathrm{~cm}^{-1}$, and $6 \mathrm{~B}_{\mathrm{g}}$ modes are located at 
$215,327,376,496,531$ and $608 \mathrm{~cm}^{-1}$. These mostly strong and well-separated peaks observed in the $150-650 \mathrm{~cm}^{-1}$ domain are sufficiently well defined to assert that they correspond to the monoclinic phase. However, $5 \mathrm{E}_{\mathrm{g}}$ active modes located at 266, 408 and $415 \mathrm{~cm}^{-1}, 1 \mathrm{Ag}_{\mathrm{g}}$ at 473 $\mathrm{cm}^{-1}$ and $1 \mathrm{~B}_{1 \mathrm{~g}}$ mode at $583 \mathrm{~cm}^{-1}$ correspond to the tetragonal phase contained in $\mathrm{ZrO}_{2}$. For the $\mathrm{Ce}_{0.25} \mathrm{Zr}_{0.75} \mathrm{O}_{2}$ nanopowder (Figure $\left.4 \mathrm{~b}\right)$ active modes are visible at $232\left(\mathrm{~B}_{1 \mathrm{~g}}\right), 311\left(\mathrm{~B}_{1 \mathrm{~g}}\right), 456$ $\left(\mathrm{E}_{\mathrm{g}}\right), 472\left(\mathrm{E}_{\mathrm{g}}\right), 608\left(\mathrm{~A}_{1 \mathrm{~g}}\right)$ and $835\left(\mathrm{E}_{\mathrm{g}}\right) \mathrm{cm}^{-1}$ corresponding to the tetragonal $\mathrm{ZrO}_{2}\left(\mathrm{~A}_{1 \mathrm{~g}}+2 \mathrm{~B}_{1 \mathrm{~g}}+\right.$ $\left.3 \mathrm{E}_{\mathrm{g}}\right)$. These band broadenings, resulting from cationic substitution in $\mathrm{ZrO}_{2}$ by $\mathrm{Ce}^{\mathrm{n}+}(\mathrm{n}=3,4)$, reveal the presence of a locally slightly disordered phase due to the strain imposed by larger cerium cations. For the $\mathrm{Ce}_{0.50} \mathrm{Zr}_{0.50} \mathrm{O}_{2}$ powder (Figure 4c), 4 main broad bands are visible at 345, 462, 625 and $835 \mathrm{~cm}^{-1}$ attributable to a tetragonal phase. Raman spectrum of the $\mathrm{Ce}_{0.75} \mathrm{Zr}_{0.25} \mathrm{O}_{2}$ powder (Figure $4 \mathrm{~d}$ ), on the other hand, tends to display the cubic $\mathrm{CeO}_{2}$ structure $(\mathrm{Fm}-3 \mathrm{~m})$. For a pure cubic structure (Figure $4 \mathrm{e}$ ), there is only the triply degenerate $\mathrm{T}_{2 \mathrm{~g}}$ mode $\left(\mathrm{A}_{1} \mathrm{~g}+\mathrm{Eg}\right)$ at $461 \mathrm{~cm}^{-1}$, corresponding to a symmetric breathing of oxygen ions octahedrally coordinated to the metal cation, which remains active. In the case of $\mathrm{Ce}_{0.75} \mathrm{Zr}_{0.25} \mathrm{O}_{2}$, we can see that two other modes $\left(630\right.$ and $\left.835 \mathrm{~cm}^{-1}\right)$ are weak but still actives, meaning that the structure is not purely cubic.

Then all the fresh nanopowders were calcined at $800{ }^{\circ} \mathrm{C}$ following by wet impregnation with $10 \mathrm{wt} . \%$ of Ni. Table 3 represents the summary of the results of textural and structural properties of the $\mathrm{Ce}_{\mathrm{x}} \mathrm{Zr}_{1-\mathrm{x}} \mathrm{O}_{2}$ fresh supports, of calcined materials and of the final catalysts impregnated with 10 wt.\% of Ni. The fresh $\mathrm{Ce}_{\mathrm{x}} \mathrm{Zr}_{1-\mathrm{x}} \mathrm{O}_{2}$ samples exhibit satisfactorily high specific surface area, $\mathrm{S}_{\mathrm{BET}}$ is in the range of $140-160 \mathrm{~m}^{2} \mathrm{~g}^{-1}$, which is quite high for the ceria-zirconia mixed oxide prepared by other synthetic routes. The addition of $\mathrm{CeO}_{2}$ into zirconia leads to a creation of mixed oxides accompanied with an increase in specific surface area passing via a maximal value in the case of stoichiometric $\mathrm{Ce}_{0.50} \mathrm{Zr}_{0.50} \mathrm{O}_{2}$ material. As expected, after the calcination step the specific surface area of all investigated samples decreases. It is worthy to note, that the 
mixed $\mathrm{CeO}_{2}-\mathrm{ZrO}_{2}$ binary materials keep much higher specific surface areas $\left(\mathrm{S}_{\mathrm{BET}} 60-78 \mathrm{~m}^{2} \mathrm{~g}^{-}\right.$ $\left.{ }^{1}\right)$ than those determined for undoped zirconia $\left(\mathrm{S}_{\text {BET }} 30 \mathrm{~m}^{2} \mathrm{~g}^{-1}\right)$. The same tendency is observed for the total pore volume of the studied samples as well (Table 3). The calcination and impregnation steps induce a decrease in the total pore volume $\left(\mathrm{V}_{\mathrm{p}}\right)$ for all the samples. For ceria-rich $\mathrm{Ce}_{0.75} \mathrm{Zr}_{0.25} \mathrm{O}_{2}$ sample, the total $\mathrm{V}_{\mathrm{p}}$ decreases from 0.22 for the fresh support to 0.14 $\mathrm{cm}^{3} \mathrm{~g}^{-1}$ after calcination at $800{ }^{\circ} \mathrm{C}$ and further impregnation. These two steps, calcination and impregnation, also induce an increase in the pore diameter $\left(D_{p}\right)$, probably indicating the sintering of small initial nanocrystals and blocking of the small pores with supported $\mathrm{NiO}$ particles, so the pore diameter in the range of 10-20 nm might be simply attributed to the intraparticle porosity.

Table 3. Textural and structural properties of the materials

\begin{tabular}{|c|c|c|c|c|c|}
\hline Catalyst & $\begin{array}{l}\text { SBEt, } \\
\mathbf{m}^{2} \mathbf{g}^{-1}\end{array}$ & $\mathrm{D}_{\mathrm{p}}, \mathbf{n m}$ & $\begin{array}{c}V_{p} \\
\mathrm{~cm}^{3} \mathrm{~g}^{-1}\end{array}$ & $\begin{array}{c}D_{\text {sup }}, \\
n m\end{array}$ & $\begin{array}{c}D_{\mathrm{NiO}} \\
\mathbf{n m}\end{array}$ \\
\hline$\overline{\mathrm{ZrO}_{2}}$ & 151 & - & 0.26 & 5 & - \\
\hline $\mathrm{ZrO}_{2}-800$ & 30 & 18 & 0.12 & 22 & - \\
\hline $\mathrm{Ni} / \mathrm{ZrO}_{2}$ & 22 & 22 & 0.08 & 25 & 24 \\
\hline $\mathrm{Ce}_{0.25} \mathrm{Zr}_{0.75} \mathrm{O}_{2}$ & 153 & - & 0.27 & 5 & - \\
\hline $\mathrm{Ce}_{0.25} \mathrm{Zr}_{0.75} \mathrm{O}_{2}-800$ & 78 & 11 & 0.22 & 10 & - \\
\hline $\mathrm{Ni} / \mathrm{Ce}_{0.25} \mathrm{Zr}_{0.75} \mathrm{O}_{2}$ & 42 & 13 & 0.15 & 11 & 21 \\
\hline $\mathrm{Ce}_{0.50} \mathrm{Zr}_{0.50} \mathrm{O}_{2}$ & 164 & - & 0.27 & 5 & - \\
\hline $\mathrm{Ce}_{0.50} \mathrm{Zr}_{0.50} \mathrm{O}_{2}-800$ & 73 & 11 & 0.22 & 9 & - \\
\hline $\mathrm{Ni} / \mathrm{Ce}_{0.50} \mathrm{Zr}_{0.50} \mathrm{O}_{2}$ & 42 & 15 & 0.16 & 11 & 17 \\
\hline $\mathrm{Ce}_{0.75} \mathrm{Zr}_{0.25} \mathrm{O}_{2}$ & 146 & - & 0.22 & 6 & - \\
\hline $\mathrm{Ce}_{0.75} \mathrm{Zr}_{0.25} \mathrm{O}_{2}-800$ & 60 & 13 & 0.20 & 10 & - \\
\hline $\mathrm{Ni} / \mathrm{Ce}_{0.75} \mathrm{Zr}_{0.25} \mathrm{O}_{2}$ & 33 & 18 & 0.14 & 11 & 23 \\
\hline $\mathrm{Ce}_{0.50} \mathrm{Zr}_{0.50} \mathrm{O}_{2}$-ind & 102 & 9 & 0.19 & 9 & - \\
\hline $\mathrm{Ni} / \mathrm{Ce}_{0.50} \mathrm{Zr}_{0.50} \mathrm{O}_{2}$-ind & 36 & 16 & 0.15 & 10 & 35 \\
\hline
\end{tabular}


$D_{p}=$ pore diameter; $V_{p}=$ pore volume, $D=$ size of crystalline domain calculated from XRD results; sup =support;- = not applicable

The crystalline domain sizes of the calcined supports and those of the supported $\mathrm{NiO}$ particles were calculated from XRD data using Scherrer equation (Table 3). The XRD patterns of calcined and impregnated samples are shown in Supplementary material (Figure S2). In the case of NiO-containing samples, the crystalline domain sizes determined for samples based on mixed ceria-zirconia supports increase from 5-6 nm (Table 2) to $11 \mathrm{~nm}$ (Table 3), whatever the composition. The structure of the $\mathrm{ZrO}_{2}$ materials underwent distinct changes during calcination step at $800{ }^{\circ} \mathrm{C}$ and further calcination after $\mathrm{Ni}$ impregnation: the increase in the crystalline domain sizes from 5 to $22 \mathrm{~nm}$ and 22 to $25 \mathrm{~nm}$ indicates more important sintering of the initial nanocrystals comparing to the mixed ceria-zirconia samples (Table 3). The crystalline domain size calculated from XRD results of the mixed oxide supports $(10-11 \mathrm{~nm}$, Table 3$)$ is smaller than that determined for pure $\mathrm{ZrO}_{2}(22-25 \mathrm{~nm})$, indicating that the presence of $\mathrm{CeO}_{2}$ is desired to stabilize the structure of $\mathrm{Ce}_{\mathrm{x}} \mathrm{Zr}_{1-\mathrm{x}} \mathrm{O}_{2}$ materials after calcination and after impregnation with nickel.

Figure 5 presents the SEM images of the $\mathrm{Ce}_{0.75} \mathrm{Zr}_{0.25} \mathrm{O}_{2}$ materials. It can be observed that the light, flake-like morphology characteristic of the fresh support (Figure 5a) turned after calcination step into a granulated structure (Figure $5 \mathrm{~b}$ and $5 \mathrm{c}$ ). It is consistent with the previous determined crystalline domain sizes and is additionally confirmed by a decrease of the specific surface area from $146 \mathrm{~m}^{2} \mathrm{~g}^{-1}$ for $\mathrm{Ce}_{0.75} \mathrm{Zr}_{0.25} \mathrm{O}_{2}$ down to $60 \mathrm{~m}^{2} \mathrm{~g}^{-1}$ for $\mathrm{Ce}_{0.75} \mathrm{Zr}_{0.25} \mathrm{O}_{2}-800$ and down to $33 \mathrm{~m}^{2} \mathrm{~g}^{-1}$ for $\mathrm{Ni} / \mathrm{Ce}_{0.75} \mathrm{Zr}_{0.25} \mathrm{O}_{2}$.

The mean size of the crystalline domains of $\mathrm{NiO}$ ranges between $17 \mathrm{~nm}$ for $\mathrm{Ni} / \mathrm{Ce}_{0.50} \mathrm{Zr}_{0.50} \mathrm{O}_{2}$ and $24 \mathrm{~nm}$ for $\mathrm{Ni} / \mathrm{ZrO}_{2}$. 


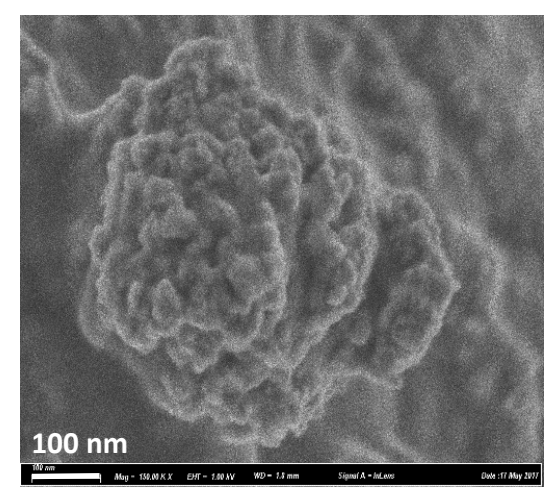

a) $\mathrm{Ce}_{0.75} \mathrm{Zr}_{0.25} \mathrm{O}_{2}$

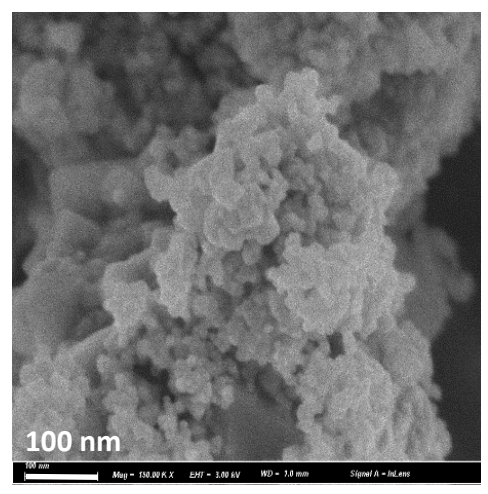

b) $\mathrm{Ce}_{0.75} \mathrm{Zr}_{0.25} \mathrm{O}_{2}-800$

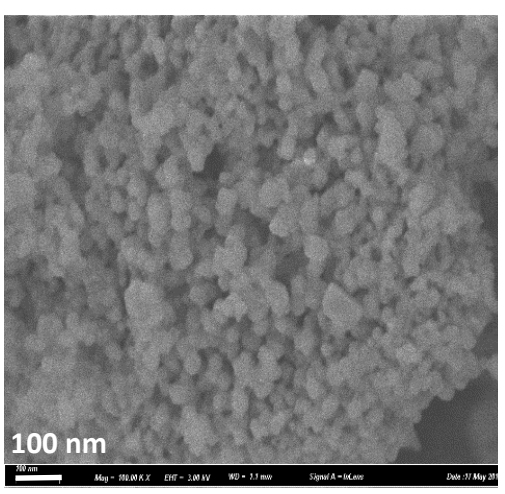

c) $\mathrm{Ni} / \mathrm{Ce}_{0.75} \mathrm{Zr}_{0.25} \mathrm{O}_{2}-800$

Figure 5. SEM images of the fresh, calcined and impregnated with $10 \mathrm{wt} \%$ of Ni materials $\left(\mathrm{Ce}_{0.75} \mathrm{Zr}_{0.25} \mathrm{O}_{2}\right)$.

An industrial ceria-zirconia mixed support was used to prepare a reference nickel-containing catalyst $\mathrm{Ni} / \mathrm{Ce}_{0.50} \mathrm{Zr}_{0.50} \mathrm{O}_{2}$-ind of the same composition as $\mathrm{Ni} / \mathrm{Ce}_{0.50} \mathrm{Zr}_{0.50} \mathrm{O}_{2}$. The characterization results of this reference support and its corresponding catalyst are reported in Table 3. Comparing $\mathrm{Ni} / \mathrm{Ce}_{0.50} \mathrm{Zr}_{0.50} \mathrm{O}_{2}$-ind and $\mathrm{Ni} / \mathrm{Ce}_{0.50} \mathrm{Zr}_{0.50} \mathrm{O}_{2}$, it clearly appears that despite similar BET surfaces (36 and $42 \mathrm{~m}^{2} \mathrm{~g}^{-1}$, respectively), similar crystalline domain sizes of the support (10 and $11 \mathrm{~nm}$, respectively) the crystalline domain size of $\mathrm{NiO}$ is twice bigger for industrial-based catalyst compared to nanostructured catalyst prepared in supercritical conditions (35 and $17 \mathrm{~nm}$, respectively). This is probably due to the stronger metal-support interaction in case of the use of the nanostructured support supposing much better metal dispersion and higher metallic surface area. The $\mathrm{H}_{2}$ adsorption results allowed to calculate these values: nickel metallic surface area for nanostructured material with the support prepared by continuous supercritical solvothermal method is 5 times higher than the nickel metallic surface area for the sample with the reference support prepared by conventional coprecipitation method (5.6 and $1.2 \mathrm{~m}^{2} \mathrm{~g}^{-1}$, respectively, Table 5). 


\subsection{Catalytic activity results}

The results of the catalytic activity of the pre-reduced $\mathrm{Ni} / \mathrm{Ce}_{\mathrm{x}} \mathrm{Zr}_{1-\mathrm{x}} \mathrm{O}_{2}$ catalysts in the reaction of dry reforming of methane are summarized in Table 4 for different reaction temperatures. It is noticeable that the sample based on $\mathrm{ZrO}_{2}$ nanoparticles as support leads to similar conversions of $\mathrm{CO}_{2}$ and $\mathrm{CH}_{4}$ than those exhibited by the samples based on mixed $\mathrm{CeO}_{2}-\mathrm{ZrO}_{2}$ oxides. It is however very difficult to catch the differences in catalytic behavior between $\mathrm{Ni} / \mathrm{Ce}_{0.25} \mathrm{Zr}_{0.75} \mathrm{O}_{2}$, $\mathrm{Ni} / \mathrm{Ce}_{0.50} \mathrm{Zr}_{0.50} \mathrm{O}_{2}$ and $\mathrm{Ni} / \mathrm{Ce}_{0.75} \mathrm{Zr}_{0.25} \mathrm{O}_{2}$ and make a clear conclusion. All the catalysts prepared by supercritical solvothermal method seem to exhibit a good behavior towards deactivation since the conversions obtained at the cooling step are very close to those exhibited in the heating step. As an example, at $700{ }^{\circ} \mathrm{C}$, the $\mathrm{CO}_{2}$ and $\mathrm{CH}_{4}$ conversions for $\mathrm{Ni} / \mathrm{Ce}_{0.50} \mathrm{Zr}_{0.50} \mathrm{O}_{2}$ in the heating step are 61 and 36\%, respectively, and 59 and 34\%, respectively, when cooling down. At the contrary, $\mathrm{Ni} / \mathrm{Ce}_{0.50} \mathrm{Zr}_{0.50} \mathrm{O}_{2}$-ind, despite a good catalytic behavior in the heating step, presents much lower conversions in the cooling step. At $700{ }^{\circ} \mathrm{C}$, the $\mathrm{CO}_{2}$ and $\mathrm{CH}_{4}$ conversions for $\mathrm{Ni} / \mathrm{Ce}_{0.50} \mathrm{Zr}_{0.50} \mathrm{O}_{2}$-ind in the heating step are 60 and $49 \%$, respectively, and 33 and $20 \%$, respectively, when cooling down. It's a point to a bad resistance of this catalyst to deactivation under the reaction conditions. The same tendency is noticeable for the $\mathrm{H}_{2} / \mathrm{CO}$ ratio, which may serve as an indicator of the catalyst selectivity. 
Table 4. Summary of the catalytic results as function of temperature at heating and cooling steps.

\begin{tabular}{|c|c|c|c|c|c|c|c|c|}
\hline \multirow[t]{3}{*}{ Result } & \multirow[t]{3}{*}{ Catalysts } & \multicolumn{7}{|c|}{ Reaction temperature, ${ }^{\circ} \mathrm{C}$} \\
\hline & & 500 & $\mathbf{5 5 0}$ & 600 & 650 & 700 & 750 & 800 \\
\hline & & & & 600* & $650 *$ & 700* & $750 *$ & \\
\hline \multirow[t]{10}{*}{$\mathrm{CO}_{2}$ conversion, $\%$} & $\mathrm{Ni} / \mathrm{ZrO}_{2}$ & 37 & 38 & 41 & 55 & 58 & 66 & 73 \\
\hline & & - & - & 41 & 57 & 58 & - & - \\
\hline & $\mathrm{Ni} / \mathrm{Ce}_{0.25} \mathrm{Zr}_{0.75} \mathrm{O}_{2}$ & 14 & 19 & 41 & 41 & 54 & 66 & 76 \\
\hline & & - & - & 38 & 39 & 52 & - & - \\
\hline & $\mathrm{Ni} / \mathrm{Ce}_{0.50} \mathrm{Zr}_{0.50} \mathrm{O}_{2}$ & 34 & 36 & 42 & 50 & 61 & 72 & 81 \\
\hline & & - & - & 48 & 48 & 59 & - & - \\
\hline & $\mathrm{Ni} / \mathrm{Ce}_{0.75} \mathrm{Zr}_{0.25} \mathrm{O}_{2}$ & 21 & 21 & 41 & 43 & 53 & 66 & 75 \\
\hline & & - & - & 28 & 39 & 51 & - & - \\
\hline & $\mathrm{Ni} / \mathrm{Ce}_{0.50} \mathrm{Zr}_{0.50} \mathrm{O}_{2}$-ind & - & 26 & 38 & 49 & 60 & 62 & 64 \\
\hline & & - & - & 12 & - & 33 & 48 & - \\
\hline \multirow[t]{10}{*}{$\overline{\mathrm{CH}_{4} \text { conversion, } \%}$} & $\mathrm{Ni} / \mathrm{ZrO}_{2}$ & 11 & 14 & 15 & 22 & 34 & 47 & 60 \\
\hline & & - & - & 15 & 23 & 34 & - & - \\
\hline & $\mathrm{Ni} / \mathrm{Ce}_{0.25} \mathrm{Zr}_{0.75} \mathrm{O}_{2}$ & 8 & 11 & 18 & 29 & 42 & 56 & 69 \\
\hline & & - & - & 17 & 27 & 41 & - & - \\
\hline & $\mathrm{Ni} / \mathrm{Ce}_{0.50} \mathrm{Zr}_{0.50} \mathrm{O}_{2}$ & 3 & 7 & 13 & 22 & 36 & 53 & 68 \\
\hline & & - & - & 5 & 19 & 34 & - & - \\
\hline & $\mathrm{Ni} / \mathrm{Ce}_{0.75} \mathrm{Zr}_{0.25} \mathrm{O}_{2}$ & 13 & 14 & 20 & 30 & 43 & 57 & 69 \\
\hline & & - & - & 18 & 28 & 41 & - & - \\
\hline & $\mathrm{Ni} / \mathrm{Ce}_{0.50} \mathrm{Zr}_{0.50} \mathrm{O}_{2}$-ind & - & 17 & 28 & 38 & 49 & 51 & 52 \\
\hline & & - & - & 6 & - & 20 & 33 & - \\
\hline \multirow[t]{5}{*}{$\mathrm{H}_{2} / \mathrm{CO}$ molar ratio } & $\mathrm{Ni} / \mathrm{ZrO}_{2}$ & - & 0.67 & 0.72 & 0.79 & 0.90 & 1.00 & 1.08 \\
\hline & & - & - & 0.75 & 0.86 & 0.96 & - & - \\
\hline & $\mathrm{Ni} / \mathrm{Ce}_{0.25} \mathrm{Zr}_{0.75} \mathrm{O}_{2}$ & 0.45 & 0.52 & 0.58 & 0.68 & 0.77 & 0.85 & 0.91 \\
\hline & & - & - & 0.57 & 0.67 & 0.77 & - & - \\
\hline & $\mathrm{Ni} / \mathrm{Ce}_{0.50} \mathrm{Zr}_{0.50} \mathrm{O}_{2}$ & 0.56 & 0.62 & 0.68 & 0.73 & 0.79 & 0.87 & 0.92 \\
\hline
\end{tabular}




\begin{tabular}{lcccccccc}
\cline { 2 - 8 } $\mathrm{Ni} / \mathrm{Ce}_{0.75} \mathrm{Zr}_{0.25} \mathrm{O}_{2}$ & - & - & 0.58 & 0.69 & 0.78 & - & - \\
\cline { 2 - 8 } & 0.65 & 0.70 & 0.77 & 0.84 & 0.95 & 1.06 & 1.11 \\
$\mathrm{Ni} / \mathrm{Ce}_{0.50} \mathrm{Zr}_{0.50} \mathrm{O}_{2}$-ind & - & - & 0.72 & 0.85 & 0.96 & - & - \\
\cline { 2 - 8 } & - & & & & & & & \\
& - & - & 0.70 & 0.75 & 0.79 & 0.84 & 0.85 & 0.85 \\
& & & & & 0.56 & 0.66 & - & -
\end{tabular}

* at the cooling step

Better understanding of the catalytic behavior of those materials may be achieved by analyzing the isothermal catalytic tests at $700{ }^{\circ} \mathrm{C}$ that give an insight into the sample stability (Figure 6).
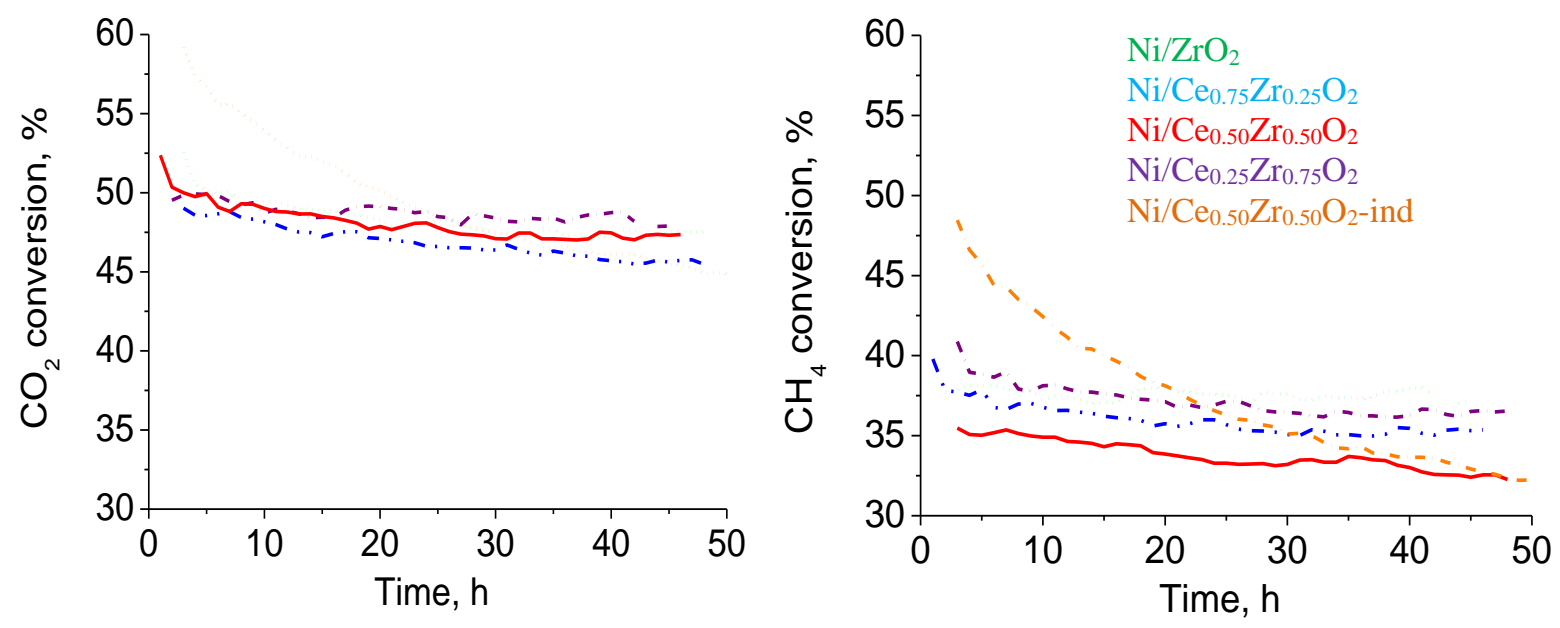

Figure 6. Isothermal tests at $700{ }^{\circ} \mathrm{C}: \mathrm{CO}_{2}$ and $\mathrm{CH}_{4}$ conversions vs time on stream.

Once again the activity of all the catalysts prepared by continuous supercritical solvothermal method appears very similar (Figure 6). The slope of deactivation $v$ s time on stream is identical for all samples, the $\mathrm{CO}_{2}$ conversion decreased from 49-52 to $46-50 \%$ over 50 hours. To have a better indication on the catalytic activities longer time-on-stream tests or the use of harsher conditions of DRM are needed. Anyway it can be seen that the deactivation is much more pronounced for the sample with the reference support, $\mathrm{Ni} / \mathrm{Ce}_{0.50} \mathrm{Zr}_{0.50} \mathrm{O}_{2}$-ind: the $\mathrm{CO}_{2}$ 
conversion decreased from 59 to $45 \%$ over 50 hours. The same tendency is observed for methane conversion. It confirms the fast deactivation probably due to intensive coking of the catalyst surface.

For more convincing comparison, the turnover frequency (TOF, $\mathrm{s}^{-1}$ ) was calculated for the initial activity point of the two samples with the same composition, $\mathrm{Ni} / \mathrm{Ce}_{0.50} \mathrm{Zr}_{0.50} \mathrm{O}_{2}$ and $\mathrm{Ni} / \mathrm{Ce}_{0.50} \mathrm{Zr}_{0.50} \mathrm{O}_{2}$-ind, using the experimentally determined metallic nickel surface (Table 5). The nanostructured material shows a TOF 7 times higher comparing to the value obtained for $\mathrm{Ni} / \mathrm{Ce}_{0.50} \mathrm{Zr}_{0.50} \mathrm{O}_{2}$-ind sample, 4.7 and $0.7 \mathrm{~s}^{-1}$, respectively. This indicates very high intrinsic activity of metallic nickel sites dispersed on $\mathrm{CeO}_{2}-\mathrm{ZrO}_{2}$ synthesized via continuous supercritical solvothermal route.

Table 5. Catalytic properties of the impregnated materials.

\begin{tabular}{|c|c|c|c|c|}
\hline Catalyst & $\begin{array}{c}\mathrm{S}_{\mathrm{Ni}} \\
\mathbf{m}^{2} \mathbf{g}^{-1}\end{array}$ & $\begin{array}{c}\text { TOF, } \\
\mathbf{s}^{-1}\end{array}$ & $\begin{array}{c}\text { CFR, } \\
\operatorname{mmol}_{\mathrm{C}} \mathrm{g}_{\mathrm{cat}}{ }^{-1} \mathbf{h}^{-1}\end{array}$ & $\begin{array}{l}\text { Coke selectivity, } \\
\text { mmolc }_{\mathrm{C}} \mathrm{mol}^{-1} \mathrm{Cconv}\end{array}$ \\
\hline$\overline{\mathrm{Ni} / \mathrm{ZrO}_{2}}$ & - & - & 0.45 & 0.20 \\
\hline $\mathrm{Ni} / \mathrm{Ce}_{0.25} \mathrm{Zr}_{0.75} \mathrm{O}_{2}$ & - & - & 0.34 & 0.16 \\
\hline $\mathrm{Ni} / \mathrm{Ce}_{0.50} \mathrm{Zr}_{0.50} \mathrm{O}_{2}$ & 1.2 & 4.7 & 0.08 & 0.038 \\
\hline $\mathrm{Ni} / \mathrm{Ce}_{0.75} \mathrm{Zr}_{0.25} \mathrm{O}_{2}$ & - & - & 0.13 & 0.058 \\
\hline $\mathrm{Ni} / \mathrm{Ce}_{0.50} \mathrm{Zr}_{0.50} \mathrm{O}_{2}$-ind & 5.6 & 0.7 & 3.43 & 1.4 \\
\hline
\end{tabular}




\subsection{Study of the spent catalysts}

In order to better understand the behavior of the samples under isothermal catalytic conditions at $700{ }^{\circ} \mathrm{C}$, two additional characterizations were performed: XRD of the spent samples and carbon deposit analysis by TPO-TGA.

X-ray diffraction patterns of the spent samples are shown in Figure 7 as well as in the supplementary material in Figure S2 for the comparison with the catalysts before catalytic tests. All the three samples based on mixed ceria-zirconia oxides prepared by supercritical solvothermal method show a little segregation of the pure $\mathrm{CeO}_{2}$ phase after $50 \mathrm{~h}$ of catalytic test at $700{ }^{\circ} \mathrm{C}$. This might indicate that as-prepared nanostructured materials are not entirely stable under continuous high temperature treatment. Probably longer calcination step would be needed with slower heating rate in order to get better stabilization of the mixed oxide nanostructures before their use in DMR. Another explanation might consist in the possible slow loss of the structured water from zirconium polyhydroxo-oligomers which are formed in the presence of water during materials' synthesis and stabilized in the nano-structure. Probably, the supercritical synthesis without use of water but only pure alcohols could be a solution to avoid the phase segregation and to stabilize the mixed oxide nanostructure. Nevertheless, the presence of such segregation did not influence the catalytic activity in DRM. There is no visible graphitic carbon which reflection appears at $2 \Theta$ equal to $c a .26^{\circ}$ [27].

It is noticed that the XRD pattern of $\mathrm{Ni} / \mathrm{Ce}_{0.50} \mathrm{Zr}_{0.50} \mathrm{O}_{2}$-ind after test does not show any phase change of the mixed ceria-zirconia structure. But in the same time it shows the wide peak at $2 \Theta$ equal to $\mathrm{ca} .26^{\circ}$ indicating a large quantity of the formed graphitic carbon. This confirms the fast deactivation trend of this sample during time-on-stream DRM test. 


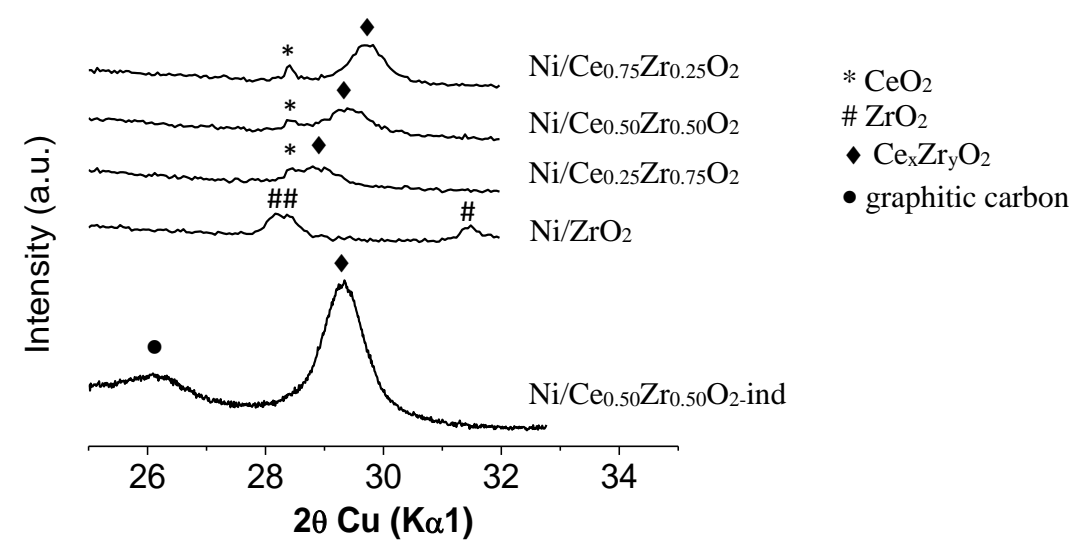

Figure 7. Diffraction patterns of the spent samples after isothermal catalytic tests at $700{ }^{\circ} \mathrm{C}$.

The TPO-TGA profiles are shown in Figure 8. There were several mass losses observed which may be divided into two groups: 1) low temperature loss at temperatures in the range 350$650^{\circ} \mathrm{C}$, may be attributed to the "reactive" carbon in forms of fibers or nanotubes, that may participate in the overall reaction mechanism (for example, in the Boudouard reaction); 2) high temperature loss at temperatures in the range $650-850{ }^{\circ} \mathrm{C}$, may correspond to the graphitic carbon, the main cause of deactivation as it covers the metallic nickel particles and reduces the number of active sites [34].

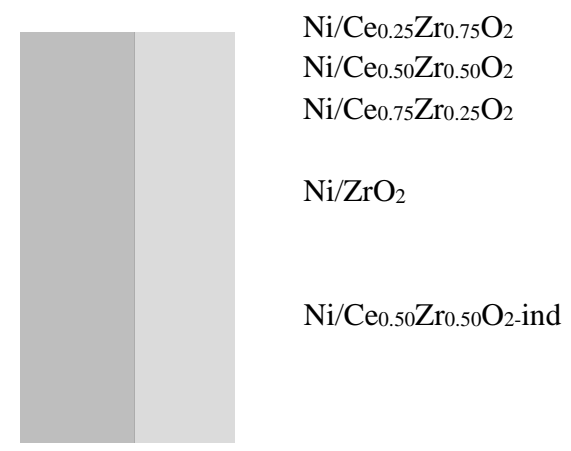

Figure 8. TPO-TGA profiles of spent samples after isothermal catalytic tests at $700{ }^{\circ} \mathrm{C}$. 
In order to compare the selectivity of the catalysts to the coke formation, the carbon formation rate (CFR) was calculated in mmol of carbon formed per gram of catalyst per hour (Table 5). Additionally, the selectivity of the catalytic materials to carbon formation was calculated in mmol of carbon per mol of converted carbon during the reaction; the results are collected in Table 5. This analysis permits to compare the catalytic behavior and more precisely the resistance to carbon formation of the prepared materials in the DRM conditions. The catalyst based on reference support accumulated the largest quantity of carbon deposit, TPO-TGA results confirm the XRD analysis of this sample after catalytic test. Among the mixed oxides nanostructured supports the Ce-rich material $\mathrm{Ni} / \mathrm{Ce}_{0.75} \mathrm{Zr}_{0.25} \mathrm{O}_{2}$ shows the highest CFR. The presence of larger quantity of $\mathrm{Zr}$ allows decreasing the CFR, but when using pure $\mathrm{ZrO}_{2}$ as catalyst support still much more coke is formed. It was reported by Boucard et al [35] that nanostructured $\mathrm{CeO}_{2}$, prepared in supercritical water, may help to reduce the coke formation rate and increase the production of $\mathrm{H}_{2}$ in the hydrothermal conversion of biomass. This effect of nano- $\mathrm{CeO}_{2}$ is probably due to its ability of water splitting and formation of active oxygen on the catalyst surface. Oxygen storage capacity (OSC) of the $\mathrm{CeO}_{2}$ with different structures, cubic morphology and irregular-shaped, is much higher for the nanostructured nanoparticles with a small size and active tetragonal (101) facets [36, 37]. It is usually attributed to the larger exposed surface area in the smaller nanocrystals and indicates that the oxygen molecules involved in the oxygen storage/release process are located on the surface of $\mathrm{CeO}_{2}$ [38]. Addition of the $\mathrm{ZrO}_{2}$ to $\mathrm{CeO}_{2}$ and formation of the mixed oxide nanostructure helps increase the specific surface area and to stabilize the tetragonal structure of $\mathrm{CeO}_{2}$.

Comparing the CFR of the ceria-zirconia materials after DRM catalytic test (Table 5) allows making a conclusion that an optimal $\mathrm{Ce} / \mathrm{Zr}$ ratio in the support is needed for improving the resistance to coke of the catalyst. The optimal catalyst which forms less coke and more importantly less graphitic coke than the other samples is the $\mathrm{Ni} / \mathrm{Ce}_{0.50} \mathrm{Zr}_{0.50} \mathrm{O}_{2}$ material 
(stoichiometric $\mathrm{Ce} / \mathrm{Zr}$ ratio). In comparison the reference sample of the same composition showed the highest CFR that indicates clearly the advantages of the proposed synthesis in continuous supercritical media regarding the formation of $\mathrm{CeO}_{2}-\mathrm{ZrO}_{2}$ nanostructured supports with high OSC (was not measured due to the very small quantity of nanostructured samples).

A correlation between the crystalline domain size of the ceria-zirconia support and the supported $\mathrm{NiO}, \mathrm{Ce} / \mathrm{Zr}$ ratio in the support from one side and the catalytic activity in DRM and coke resistance from the other side may be done. The smallest crystalline domain size of $\mathrm{NiO}$ $17 \mathrm{~nm}$ as the precursor of nickel metallic active sites was possible to achieve using the mixed oxide support of stoichiometric ratio of ceria and zirconia that offered the best metal-support interaction. Based on the current study, it can be stated that, the smaller is the crystalline domain size of the mixed oxide support, the better performance in DRM may be expected as well as better resistance to coking. The nanostructured supports were obtained due to the specific conditions of the synthesis in supercritical medium. The nanostructured $\mathrm{Ce}_{\mathrm{x}} \mathrm{Zr}_{1-\mathrm{x}} \mathrm{O}_{2}$ materials are found to be promising supports not only for nickel but for other active metals dispersion and for coke control in the reactions where coking is abundant.

\section{Conclusions}

In this work a family of nanostructured $\mathrm{Ce}_{\mathrm{x}} \mathrm{Zr}_{1-\mathrm{x}} \mathrm{O}_{2}(0 \leq \mathrm{x} \leq 0.75)$ materials was prepared by continuous supercritical solvothermal method. They were calcined at $800{ }^{\circ} \mathrm{C}$ and then impregnated with $10 \mathrm{wt} . \%$ of nickel. All the prepared materials as well as one reference sample

with the same composition were characterized; Ni-containing materials were studied in catalysis of DRM with characterization of spent materials after tests. 
Fresh supports $\mathrm{Ce}_{\mathrm{x}} \mathrm{Zr}_{1-\mathrm{x}} \mathrm{O}_{2}$ before calcination step have shown the formation of ceria-zirconia mixed oxides. After calcination and impregnation steps in the sample $\mathrm{ZrO}_{2}$ without incorporation of ceria the crystalline domain size was observed around $22-25 \mathrm{~nm}$. The incorporation of ceria helps to stabilize the ceria-zirconia mixed oxides with much smaller crystalline domain size around 10-11 nm; it also improves the activity in DRM and decreased the formation of carbon deposit during the catalytic tests. The carbon deposit analysis after DRM tests revealed that the carbon deposit rate was more important for the $\mathrm{ZrO}_{2}$ sample and much more important for the reference sample. The optimal composition of the nanostructured support is $\mathrm{Ce}_{0.50} \mathrm{Zr}_{0.50} \mathrm{O}_{2}$, with the stoichiometric $\mathrm{Ce} / \mathrm{Zr}$ ratio, which shows a higher activity in DRM and lower coke formation rate in comparison to the reference sample with the same composition. The continuous supercritical solvothermal method allows to prepare nanostructured mixed oxides materials that could be promising supports for different active metals dispersion and for coke control in the reactions where coking may be abundant.

\section{Acknowledgements}

The authors acknowledge the European ERANet RUS Plus program for financial support in the frames of the project " $\mathrm{NiCe}$ - Design of $\mathrm{Ni} /$ ceria-zirconia nanomaterials by continuous synthesis in supercritical medium: tuning catalytic properties". This work was performed as a part of the large international collaboration GDRI "Catalytic valorization of biomass" supported by CNRS in France and RFBR in Russia. The Polish authors thank for the financial support the National Centre for Research and Development in the framework of NiCe ERANet RUS Plus - S\&T project (5/RUSPLUS - S\&T/2016). Katarzyna Dziadek acknowledges the Erasmus+ Program for the financial support. Aimery Auxemery acknowledges the Innovation Fund Denmark in the frames of the GCAM project for the financial support. The authors from ICMCB acknowledge CNRS, the University of Bordeaux and Bordeaux INP and also the "Région 
Nouvelle-Aquitaine" for their financial support. The authors thank Dr Thierry Dintzer for fruitful discussion on the SEM results.

\section{References}

[1] S. Block, J. A. H. Da Jornada, G. J. Piermarini, Pressure-Temperature Phase Diagram of Zirconia. J. Am. Ceram. Soc. 68, 1985, pp. 497-499

[2] E. H. Kisi, C. J. Howard, Crystal Structures of Zirconia Phases and their Inter-Relation. Key Eng. Mater. 153-154, 1998, pp. 1-36

[3] A. C. Dippel, K. M. Ø. Jensen, C. Tyrsted, M. Bremholm, E. D. Bøjesen, D. Saha, S. Birgisson, M. Christensen, S. J. L. Billinge, B. B. Iversen, Towards atomistic understanding of polymorphism in the solvothermal synthesis of $\mathrm{ZrO}_{2}$ nanoparticles. Acta Crystallogr. Sect. Found. Adv.72, 2016, pp. 645-650

[4] S. Shukla, S. Seal, Mechanisms of room temperature metastable tetragonal phase stabilisation in zirconia. Int. Mater. Rev. 50, 2005, pp. 45-64

[5] J. Becker, P. Hald, M. Bremholm, J.S. Pedersen, J. Chevallier, S. B. Iversen, B. B. Iversen, Critical Size of Crystalline $\mathrm{ZrO}_{2}$ Nanoparticles Synthesized in Near- and Supercritical Water and Supercritical Isopropyl Alcohol. ACS Nano 2, 2008, pp. 1058-1068

[6] N. S. Priya, C. Somayaji, S. Kanagaraj, Optimization of Ceria-Zirconia Solid Solution based on OSC Measurement by Cyclic Heating Process. Procedia Eng. 64, 2013, pp. 1235-1241

[7] J. R. Kim, W. J. Myeong, S. K. Ihm, Characteristics in oxygen storage capacity of ceriazirconia mixed oxides prepared by continuous hydrothermal synthesis in supercritical water. Applied Catalysis B: Environmental 71, 2007, pp. 57-63

[8] C. Slostowski, S. Marre, P. Dagault, O. Babot, T. Toupance, C. Aymonier, $\mathrm{CeO}_{2}$ nanopowders as solid sorbents for efficient $\mathrm{CO}_{2}$ capture/release processes. J. $\mathrm{CO}_{2}$ Util.20, 2017, pp. 52-58

[9] M. Ozawa, M. Takahashi-Morita, K. Kobayashi, M. Haneda, Core-shell type ceria zirconia support for platinum and rhodium three way catalysts. Catal. Today 281, 2018, pp. 482-489 

catalysis. Catal. Today 50, 1999, pp. 285-298 changes in cerium-based oxides nanoparticles during redox processes. Ultramicroscopy 108 , 2008, pp. 1432-1440

[12] M. Tsang, G. Philippot, C. Aymonier, G. Sonnemann, Anticipatory life-cycle assessment of supercritical fluid synthesis of barium strontium titanate nanoparticles. Green Chem. 18 (2016) 4924 - 4933 to support sustainable production of engineered nanomaterials: case study of titanium dioxide nanoparticles, ACS Sust. Chem. Eng. 6(4), 2018, pp. 5142-5151

[14] C. Aymonier, G. Philippot, A. Erriguible, S. Marre, Playing with solvents in supercritical conditions and the associated technologies for advanced materials by design. $J$. Supercrit. Fluids 134, 2018, pp. 184-196

[15] C. Slostowski, S. Marre, O. Babot, T. Toupance, C. Aymonier, $\mathrm{CeO}_{2} \mathrm{Nanocrystals}^{2}$ from Supercritical Alcohols: New Opportunities for Versatile Functionalizations? Langmuir 30, 2014, pp. 5965-5972

[16] G. Philippot, K.M.Ø. Jensen, M. Christensen, C. Elissalde, M. Maglione, B. B. Iversen, C. Aymonier, Coupling in situ synchrotron radiation with ex situ spectroscopy characterizations to study the formation of $\mathrm{Ba}_{1-\mathrm{x}} \mathrm{Sr}_{\mathrm{x}} \mathrm{TiO}_{3}$ nanoparticles in supercritical fluids. J. Supercrit. Fluids 87, 2014, pp. 111-117 M. Taguchi, S. Takami, T. Naka, T. Adschiri, Growth Mechanism and Surface Chemical Characteristics of Dicarboxylic Acid-Modified $\mathrm{CeO}_{2}$ Nanocrystals Produced in Supercritical Water: Tailor-Made Water-Soluble $\mathrm{CeO}_{2}$ Nanocrystals. Cryst. Growth Des. 9, 2009, pp. 5297-5303

[18] G. Philippot, M. Albino, U. C. Chung, M. Josse, C. Elissalde, M. Maglione, C. Aymonier, Continuous $\mathrm{BaTi}_{1-\mathrm{y}} \mathrm{Zr}_{\mathrm{y}} \mathrm{O}_{3}(0 \leq \mathrm{y} \leq 1)$ nanocrystals synthesis in supercritical fluids for nanostructured lead-free ferroelectric ceramics. Mater. Des. 86, 2015, pp. 354-360 
Supercritical Water. Materials 3, 2010, pp. 3794-3817

[20]

$$
\text { P. Wang, K. Ueno, H. Takigawa, K. Kobiro, Versatility of one-pot, single-step }
$$

synthetic approach for spherical porous (metal) oxide nanoparticles using supercritical alcohols. J. Supercrit. Fluids 78, 2013, pp. 124-131 nanostructures in near- and supercritical fluids. J. Supercrit. Fluids 84, 2013, pp. 89-97

Takami, T. Adschiri, Tuning surface grafting density of $\mathrm{CeO} 2$ nanocrystals with near- and supercritical solvent characteristics. Phys. Chem. Chem. Phys. 18, 2016, pp. 1727-1734

[23] C. Slostowski, S. Marre, O. Babot, T. Toupance, C. Aymonier, Near- and Supercritical Alcohols as Solvents and Surface Modifiers for the Continuous Synthesis of Cerium Oxide Nanoparticles. Langmuir 28, 2012, pp. 16656-16663 H. Reveron, C. Aymonier, A. Loppinet-Serani, C. Elissalde, M. Maglione, F. Cansell, One-pot synthesis of well-crystallized and pure barium titanate nanoparticles in supercriticals fluids. Nanotechnology 16, 2005, pp. 1137 - 1143 oxidative dry methane reforming with $\mathrm{CO}_{2}$. Int. J. of Hydrogen Energy 44, 2019, pp. 46164629

[26] K. Świrk, M. E. Gálvez, M. Motak, T. Grzybek, M. Roning, P. Da Costa, Yttrium promoted Ni-based double-layered hydroxides for dry methane reforming. J. $\mathrm{CO}_{2}$ Util 27, 2018, pp. $247-258$ Promotion over Ni-Containing Hydrotalcite-Derived Catalysts for $\mathrm{CO}_{2}$ Methane Reforming. E3S Web of Conferences 14, 2017, pp. 02039 
Phase Transformations of $\mathrm{ZrO}_{2}$. J. Am. Ceram. Soc. 57, 1974, pp. 22-24

[30] T. Hirata, E. Asari, M. Kitajima, Infrared and Raman Spectroscopic Studies of $\mathrm{ZrO}_{2}$ Polymorphs Doped with $\mathrm{Y}_{2} \mathrm{O}_{3}$ or $\mathrm{CeO}_{2}$. J. Solid State Chem. 110, 1994, pp. 201-207

[31] W. H. Weber, K. C. Hass, J. R. McBride, Raman study of $\mathrm{CeO}_{2}$ : Second-order scattering, lattice dynamics, and particle-size effects. Phys. Rev. B 48, 1993, pp. 178-185

X-ray Photoelectron Spectroscopy Study of $\mathrm{CeO}_{2}-\mathrm{ZrO}_{2}$ and $\mathrm{V}_{2} \mathrm{O}_{5} / \mathrm{CeO}_{2}-\mathrm{ZrO}_{2}$ Catalysts.

Langmuir 19, 2003, pp. 3025-3030

D. Michel, M. Perez y Jorba, R. Collongues, Study by Raman spectroscopy of orderdisorder phenomena occurring in some binary oxides with fluorite-related structures. Journal of Raman Spectroscopy 5(2), 1976, pp. 163-180

Muhler, The role of carbonaceous deposits in the activity and stability of Ni-based catalysts applied in the dry reforming of methane. Catalysis Science and Technology 4, 2014, pp. 33173328

H. Boucard, M. Watanabe, S. Takami, E. Weiss-Hortala, R. Barna, T. Adschiri, Beneficial use of $\mathrm{CeO}_{2}$ nanocatalyst for black liquor conversion under sub and supercritical conditions. Journal of Supercritical Fluids 105, 2015, pp. 66-76

[36] J. Zhang, H. Kumagai, K. Yamamura, S. Ohra, S. Takami, A. Morikawa, H. Shinjoh, K. Kaneko, T. Adschiri, A. Suda, Extra-low temperature oxygen storage capacity of $\mathrm{CeO}_{2}$ nanocrystals with cubic facets. Nano Letters 11, 2011, pp. 361-364

Kishita, T. Adschiri, Catalytic Cracking Reaction of Heavy Oil in the Presence of Cerium Oxide Nanoparticles in Supercritical Water. Energy Fuels 27, 2013, pp. 4624-4631 